\title{
Interplay between geochemistry and magma dynamics during magma interaction: An example from the Sithonia Plutonic Complex (NE Greece)
}

\author{
G. Christofides ${ }^{\text {a }}$, D. Perugini ${ }^{\text {b,* }}$, A. Koroneos ${ }^{\text {a }}$, T. Soldatos ${ }^{\text {a }}$, G. Poli ${ }^{\text {b }}$, G. Eleftheriadis ${ }^{\text {a }}$, \\ A. Del Moro ${ }^{\mathrm{c}}$, A.M. Neiva ${ }^{\mathrm{d}}$ \\ a Department of Mineralogy, Petrology and Economic Geology, Aristotle University of Thessaloniki, GR-541 24 Thessaloniki, Macedonia, Greece \\ ${ }^{\mathrm{b}}$ Department of Earth Sciences, University of Perugia, Piazza Università, 06100 Perugia, Italy \\ ${ }^{\mathrm{c}}$ Istituto di Geocronologia e Geochimica Isotopica, CNR Pisa, Italy \\ ${ }^{\mathrm{d}}$ Department of Earth Sciences, University of Coimbra, 3000 Coimbra, Portugal
}

Received 17 October 2005; accepted 14 July 2006

Available online 11 September 2006

\begin{abstract}
Orogenic granitoids often display mineralogical and geochemical features suggesting that open-system magmatic processes played a key role in their evolution. This is testified by the presence of enclaves of more mafic magmas dispersed into the granitoid mass, the occurrence of strong disequilibrium textures in mineralogical phases, and/or extreme geochemical and isotopic variability.

In this contribution, intrusive rocks constituting the Sithonia Plutonic Complex (Northern Greece) are studied on the basis of mineral chemistry, whole-rock major, trace element geochemistry, and $\mathrm{Sr}$ and $\mathrm{Nd}$ isotopic composition. Sithonia rocks can be divided into a basic group bearing macroscopic (mafic enclaves), microscopic (disequilibrium textures), geochemical, and isotopic evidence of magma interaction, and an acid group in which most geochemical and isotopic features are consistent with a magma mixing process, but macroscopic and microscopic features are lacking.

A two-step Mixing plus Fractional Crystallization (MFC) process is considered responsible for the evolution of the basic group. The first step explains the chemical variation in the mafic enclave group: a basic magma, represented by the least evolved enclaves, interacted with an acid magma, represented by the most evolved granitoid rocks, to give the most evolved enclaves. The second step explains the geochemical variations of the remaining rocks of the basic group: most evolved enclaves interacted with the same acid magma to give the spectrum of rock compositions with intermediate geochemical signatures. A convection-diffusion process is envisaged to explain the geochemical and isotopic variability and the lack of macroscopic and petrographic evidence of magma interaction in the acid group.

The mafic magma is presumably the result of melting of a mantle, repeatedly metasomatized and enriched in LILE due to subduction events, whereas the acid magma is considered the product of partial melting of lower crustal rocks of intermediate to basaltic composition.

It is shown that Sithonia Plutonic Complex offers the opportunity to investigate in detail the complex interplay between geochemistry and magma dynamics during magma interaction processes between mantle and crustal derived magmas.
\end{abstract}

(C) 2006 Elsevier B.V. All rights reserved.

Keywords: Magma mixing; Trace element modelling; Granitoid magmatism; Northern Greece

\footnotetext{
* Corresponding author. Tel.: +39075 5852652; fax: +39075 5852603 .

E-mail address: diegop@unipg.it (D. Perugini).
} 


\section{Introduction}

Orogenic granitoids often display mineralogical and geochemical features suggesting that open-system magmatic processes played a key role in their evolution. This is testified by a variety of evidence including the presence of solidified blobs of more mafic magmas (Mafic Microgranular Enclaves, MME; e.g. Didier and Barbarin, 1991), the occurrence of strong disequilibrium textures in mineralogical phases, or extreme geochemical and isotopic variability. All these features may be recognised on a scale ranging from batholite trough single pluton to single minerals. A suitable general conceptual model to account for them is the well-known MASH (Mixing-Assimilation-Storage-Homogenization) suggested by Hildreth and Moorbath (1988). The development of such processes in space and time can generate very complex interplays between chemical and physical factors. In particular, geochemical evolution of magmas can be influenced by magma dynamics such as convection in magma chamber, magma migration and coalescence, and thermo-chemical convection.

Although several works pointed out the general importance of open-system magmatic processes in the evolution of orogenic granitoid magmatism (Didier and Barbarin, 1991 and reference therein; Perugini et al., 2003; Janousek et al., 2004), most of the authors focus on the study of single aspects, such as analyses of mafic microgranular enclaves, or detailed geochemical and isotopic studies. Only rarely the interplay between magma dynamics and geochemistry is taken into account to draw a more complete picture. A possible key to understand this interplay may consist in the selection of a suitable suite of granitoid rocks bearing evidence of open-system processes. This should be analysed in detail for a complex set of petrological and geochemical features in order to build a genetic model accounting for the evolution of the magmatic system.

This approach is employed in the present contribution, where granitoid rocks constituting the Sithonia

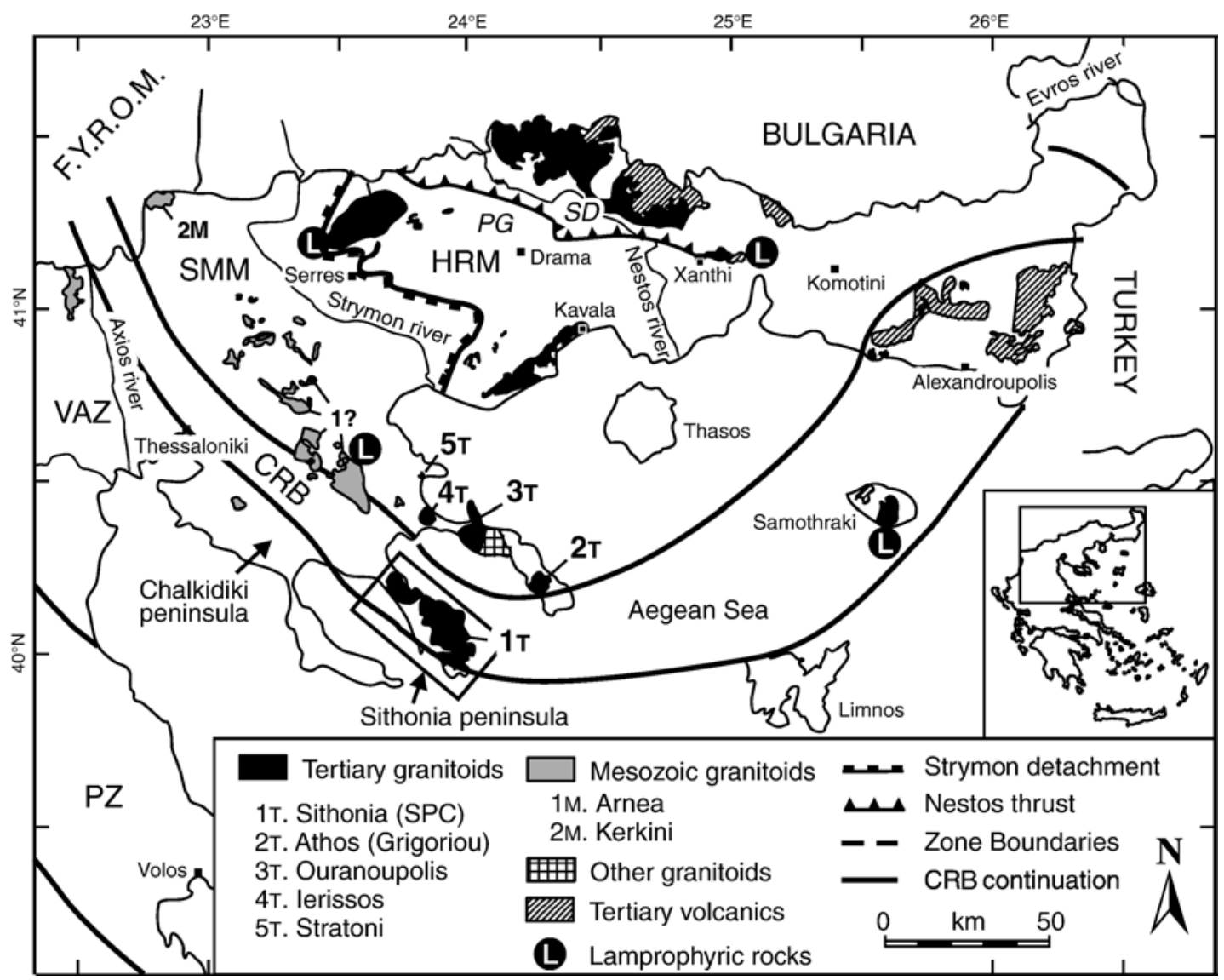

Fig. 1. Geological sketch map of the Central-Eastern part of Northern Greece. The main plutonic and volcanic outcrops are shown. VAZ, Vardar (Axios) Zone; CRB, Circum-Rhodope Belt; SMM, Serbo-Macedonian Massif; HRM, Hellenic Rhodope Massif; PZ, Pelagonian Zone; SD, Sidironero or Upper Tectonic Unit; PG, Pangeon or Lower Tectonic Unit. 
Plutonic Complex (Northern Greece), bearing clear evidence of open-system magmatic processes are studied. The Sithonia Plutonic Complex (hereafter SPC) is investigated in terms of mineral chemistry, whole-rock major and trace element geochemistry, as well as $\mathrm{Sr}$ and $\mathrm{Nd}$ isotopic composition. It is shown that Sithonia Plutonic Complex offers an opportunity to investigate in detail the complex interplay between geochemistry and magma dynamics, constraining magmatic evolution of hybrid igneous bodies. Besides, this work aims at clarifying the petrogenesis of the SPC and contributes to the understanding of the Eocene magmatism in northern Greece.

\section{The Sithonia Plutonic Complex: geological setting}

A voluminous acidic to intermediate magmatic activity has characterized the Serbo-Macedonian Massif and the Circum-Rhodope Belt of the Chalkidiki Peninsula in Northern Greece (Fig. 1). Two main magmatic phases of different age have been recognized: i) less voluminous Mesozoic (early Jurassic-early Cretaceous) magmatism with plutonic bodies (e.g. Kerkini, Arnea) and small volcanic complexes (De Wet et al., 1989; Dimitriadis and Asvesta, 1993; Christofides et al., 2000; Kostopoulos et al., 2001; Perugini et al., 2004); ii) a more intense Tertiary magmatism of mostly Eocene to Oligocene age

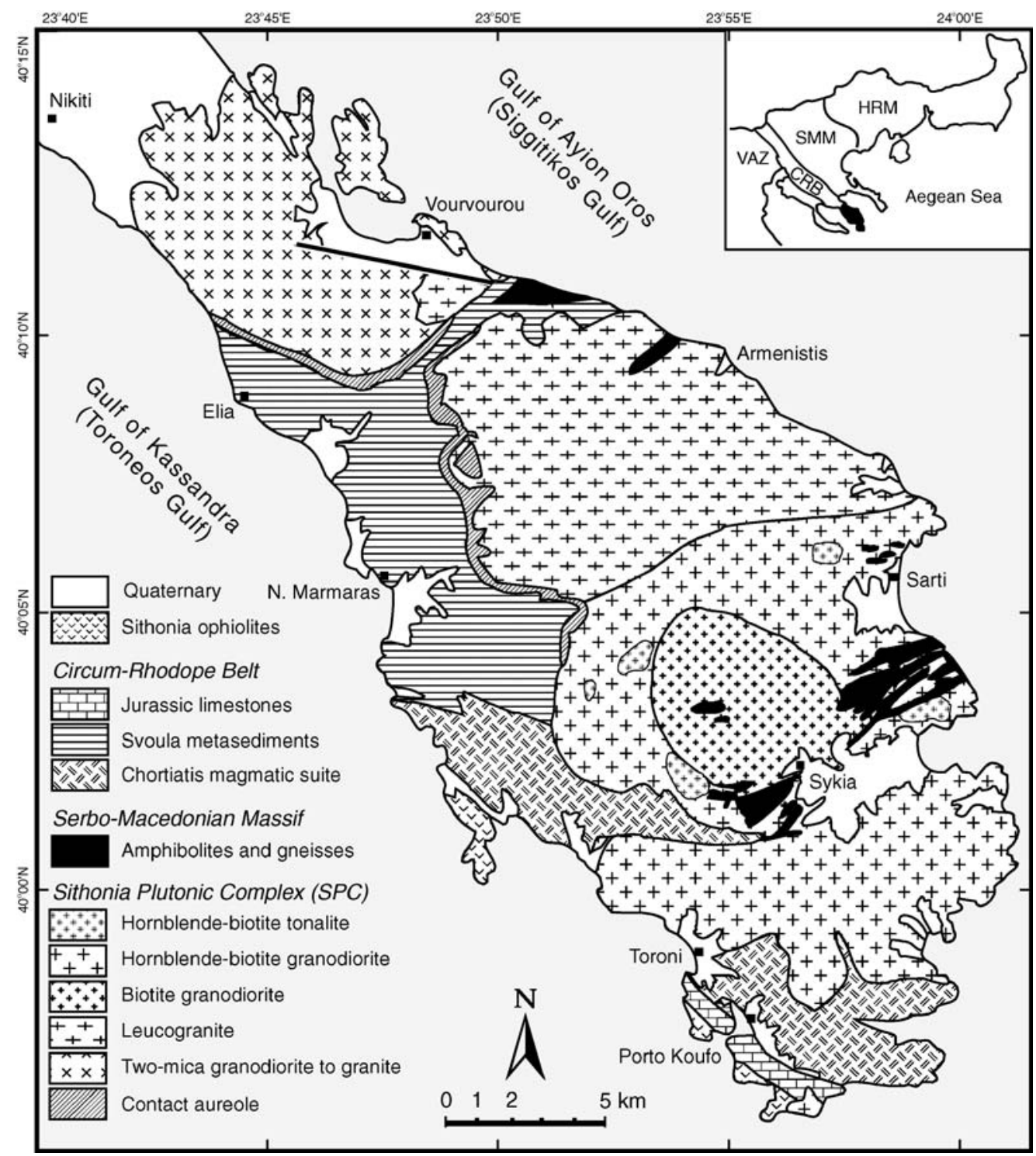

Fig. 2. Geological map of the Sithonia Plutonic Complex (SPC) and its country rocks (compiled from Michard et al., 1998; Christofides et al., 2001). 
(e.g. Sithonia, Ouranopolis, Ierissos, Athos, Stratoni; Sapountzis et al., 1976; De Wet et al., 1989; D'Amico et al., 1990; Frei, 1992; Christofides et al., 2001; Bebien et al., 2001; Pe-Piper and Piper, 2002; Perugini et al., 2004).

The Tertiary Sithonia Plutonic Complex is situated in the Sithonia Peninsula that constitutes the middle "leg" of the three-legged Chalkidiki Peninsula in Northern Greece (e.g. D'Amico et al., 1990; Christofides et al., 1990; Perugini et al., 2003, and references therein), except for its central western and southernmost parts (Fig. 2). The SPC is a NW-SE trending granitic body of about $350 \mathrm{~km}^{2}$ (Fig. 2). It intruded basement rocks of the Serbo-Macedonian Massif and the Circum Rhodope Belt (Kockel et al., 1977; Michard et al., 1998) and, according to Mussallam and Jung (1986) and Bebien et al. (1987), its southern part is in contact with the Sithonia ophiolites.

The intrusion of the SPC affected the regional NW-SE strike of the schistosity and fold axes of the country rocks, considered as a result of Middle-Jurassic tectonic activity. The intrusion itself has been affected by younger tectonic activity that took place most probably in the Late EoceneOligocene and induced minor shear effects marked by mica orientation (Sakellariou, 1989). The strongly sheared contacts between the SPC intrusives and the country rocks suggest that the emplacement probably occurred by forceful intrusion (e.g. De Wet et al., 1989; D’Amico et al., 1990). A well-defined fabric is developed mainly near the margins of the complex and locally in some internal portions, and can be related to both the emplacement and later deformational events (D'Amico et al., 1990).

The southern part of the complex (Fig. 2) consists mainly of hornblende-biotite granodiorite, intruded by a finer-grained biotite granodiorite with sharp contacts. Masses of hornblende-biotite tonalite are found as small occurrences passing gradually to hornblende-biotite granodiorite. Mafic microgranular enclaves, usually less than $30 \mathrm{~cm}$ across with rounded and elongated morphology, are found dispersed in all the above rock types. A few granodioritic porphyries, occurring as small masses and dykes cutting the granodiorites and country rocks, are also found. Small (about $50 \mathrm{~m}^{2}$ ) meta-diorite to meta-gabbro bodies occur within the hornblende-biotite granodiorite. The central part of the peninsula is occupied by the leucogranite, often with porphyritic texture, whereas the northern part is built by two-mica granodiorite to granite.

Field relationships indicate that the two-mica granodiorite to granite intruded metasediments, and is cut by the leucogranite with sharp contacts. The leucogranite penetrated the hornblende-biotite granodiorite, as indicated by the occurrence of leucogranite dykes in the latter. In addition there are also deformed masses of hornblende-biotite granodiorite, often displaying crenulated contacts, in the leucogranite. All the granitoid masses, as well as the country rocks, were intruded by pegmatitic and aplitic dykes and veins, being more abundant in the leucogranite and the two-mica granodiorite to granite than in the other rock types.

A whole-rock $\mathrm{Rb}-\mathrm{Sr}$ isochron yielded an age of $50.4 \pm$ 0.7 Ma for the two-mica granodiorite to granite (De Wet et al., 1989; Christofides et al., 1990), whereas $\mathrm{Rb}-\mathrm{Sr}$ isochrones for other rock types gave an average age of $46 \mathrm{Ma}$ on whole-rock biotite pairs (Christofides et al., 1990).

Based on discrimination diagrams of Pearce et al. (1984) and Harris et al. (1986), D'Amico et al. (1990) suggested a pre-plate or post-collision geotectonic setting for SPC, ruling out a syn-collision environment. This is also supported by a comparative study on the Tertiary granitoids of the area (Christofides et al., 2001).

\section{Petrography}

Detailed account of petrography of the SPC rocks was presented by Sapountzis et al. (1976), De Wet (1989), Christofides et al. (1990), D’Amico et al. (1990) and Perugini et al. (2003). Here the main petrographic features are summarized only briefly. Rock nomenclature is given according to the $R_{1}-R_{2}$ diagram of De La Roche et al. (1980) (Fig. 3).

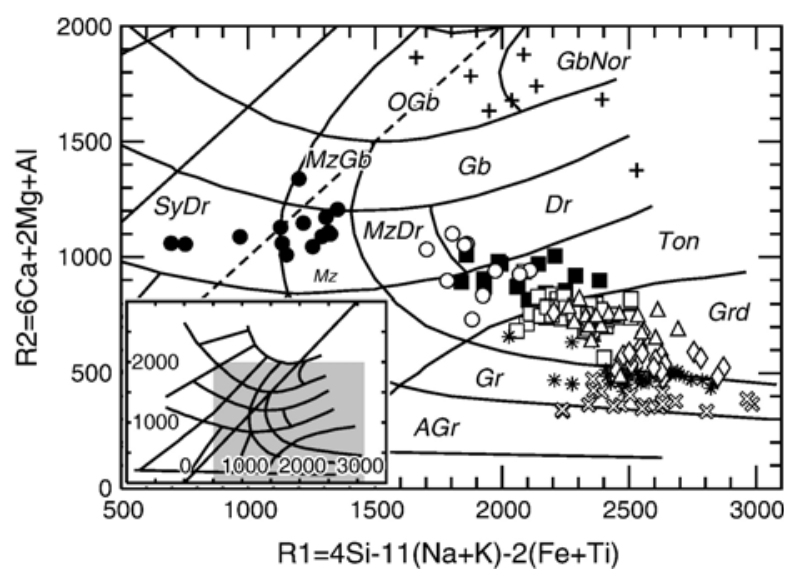

Fig. 3. Classification of SPC rocks on the basis of $R_{1}-R_{2}$ diagram (De La Roche et al., 1980). Rock types of SPC: Cross, diorite and gabbro; filled circle, monzonitic mafic microgranular enclaves; open circle, dioritic to tonalitic mafic microgranular enclaves; filled square, hornblende-biotite tonalite; open square, hornblende-biotite granodiorite; triangle, biotite granodiorite; star, leucogranite; diamond, twomica granodiorite to granite; $\mathrm{x}$, aplites and pegmatites. Rock fields on $R_{1}-R_{2}$ diagram: OGb, Olivine gabbro; GbNor, Gabbronorite; MzGb, Monzogabbro; Gb, Gabbro; SyDr, Syenodiorite; Mz, Monzonite; MzDr, Monzodiorite; Dr, Diorite; Ton, Tonalite; Grd, Granodiorite; Gr, Granite; AGr, Alkali granite. 


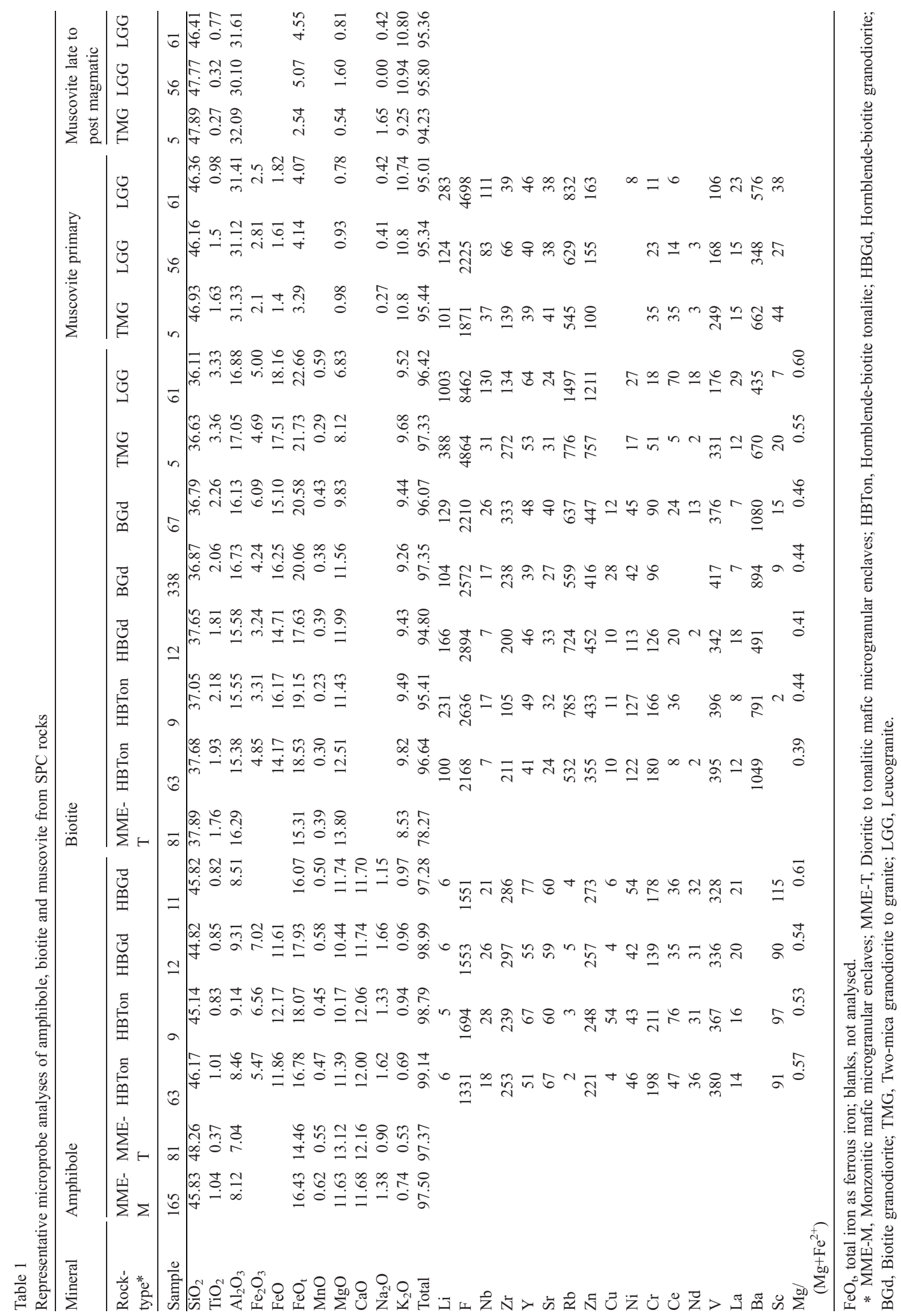


Table 2

Representative major and trace element analyses of SPC and basement rocks

\begin{tabular}{|c|c|c|c|c|c|c|c|c|c|c|c|c|c|c|c|c|c|}
\hline \multirow{2}{*}{$\begin{array}{l}\text { Rock } \\
\text { type* }^{*}\end{array}$} & \multicolumn{3}{|l|}{ MME-M } & \multicolumn{3}{|c|}{ MME-T } & \multicolumn{6}{|l|}{ HBTon } & \multicolumn{5}{|l|}{ HBGd } \\
\hline & $514 \mathrm{E}$ & 83 & $531 \mathrm{E}$ & 81 & 310 & 515 & 137 & 121 & 63 & 139 & 390 & 9 & 7 & 6 & 12 & 8 & 11 \\
\hline $\mathrm{SiO}_{2}$ & 53.50 & 56.64 & 57.33 & 58.76 & 60.79 & 63.16 & 62.57 & 63.09 & 63.98 & 64.86 & 64.92 & 64.97 & 67.22 & 67.58 & 67.83 & 68.15 & 68.42 \\
\hline $\mathrm{TiO}_{2}$ & 1.26 & 0.75 & 0.82 & 0.67 & 0.61 & 0.80 & 0.55 & 0.52 & 0.54 & 0.51 & 0.50 & 0.47 & 0.39 & 0.37 & 0.32 & 0.28 & 0.32 \\
\hline $\mathrm{Al}_{2} \mathrm{O}_{3}$ & 17.33 & 18.32 & 17.01 & 17.51 & 16.53 & 16.50 & 18.32 & 16.61 & 16.90 & 17.73 & 16.42 & 16.42 & 16.16 & 16.06 & 16.31 & 16.03 & 16.23 \\
\hline $\mathrm{Fe}_{2} \mathrm{O}_{3} \mathrm{t}$ & 8.45 & 6.28 & 6.50 & 5.70 & 5.12 & 5.65 & 4.22 & 4.71 & 3.93 & 3.86 & 3.49 & 3.52 & 2.87 & 2.77 & 2.50 & 2.19 & 2.44 \\
\hline $\mathrm{MnO}$ & 0.17 & 0.14 & 0.14 & 0.13 & 0.12 & 0.14 & 0.11 & 0.08 & 0.08 & 0.11 & 0.09 & 0.06 & 0.06 & 0.06 & 0.05 & 0.04 & 0.05 \\
\hline $\mathrm{MgO}$ & 3.39 & 3.23 & 3.30 & 3.56 & 3.71 & 1.16 & 2.13 & 2.37 & 2.20 & 2.02 & 2.11 & 1.94 & 1.38 & 1.37 & 1.26 & 1.20 & 1.27 \\
\hline $\mathrm{CaO}$ & 5.08 & 4.50 & 5.04 & 5.35 & 5.05 & 4.18 & 4.64 & 4.11 & 4.26 & 4.13 & 4.12 & 4.16 & 3.47 & 3.29 & 3.43 & 3.12 & 3.57 \\
\hline $\mathrm{Na}_{2} \mathrm{O}$ & 4.36 & 4.89 & 3.79 & 4.20 & 4.59 & 4.06 & 4.38 & 4.38 & 4.77 & 4.29 & 4.45 & 4.40 & 4.67 & 4.67 & 5.11 & 4.45 & 4.80 \\
\hline $\mathrm{K}_{2} \mathrm{O}$ & 4.58 & 3.05 & 4.44 & 1.99 & 1.81 & 2.94 & 2.18 & 2.94 & 2.31 & 1.36 & 2.55 & 2.66 & 2.70 & 2.60 & 2.31 & 3.51 & 2.15 \\
\hline $\mathrm{P}_{2} \mathrm{O}_{5}$ & 0.80 & 0.54 & 0.42 & 0.43 & 0.47 & 0.47 & 0.46 & 0.29 & 0.44 & 0.34 & 0.32 & 0.29 & 0.24 & 0.22 & 0.19 & 0.18 & 0.16 \\
\hline LOI & 1.44 & 1.66 & 1.48 & 1.70 & 1.21 & 0.96 & 0.44 & 0.89 & 0.60 & 0.79 & 1.12 & 1.11 & 0.84 & 1.01 & 0.69 & 0.86 & 0.59 \\
\hline Tot & 100.36 & 100.00 & 100.27 & 100.00 & 100.01 & 100.02 & 100.00 & 99.99 & 100.01 & 100.00 & 100.09 & 100.00 & 100.00 & 100.00 & 100.00 & 100.01 & 100.00 \\
\hline ASI & 0.81 & 0.94 & 0.84 & 0.93 & 0.88 & 0.94 & 1.02 & 0.93 & 0.93 & 1.11 & 0.93 & 0.93 & 0.96 & 0.97 & 0.95 & 0.95 & 0.97 \\
\hline $\mathrm{Cr}$ & 9 & 15 & 25 & 42 & 83 & 15 & 22 & 25 & 18 & 21 & 22 & 20 & 9 & 10 & 9 & 9 & 12 \\
\hline $\mathrm{Ni}$ & 26 & 5 & 23 & 32 & 48 & 15 & & 14 & 15 & 8 & 13 & 13 & 9 & 10 & 9 & 7 & 9 \\
\hline $\mathrm{V}$ & 116 & 109 & 129 & 106 & 99 & 72 & 78 & 72 & 78 & 76 & 64 & 62 & 49 & 48 & 42 & 37 & 44 \\
\hline $\mathrm{Rb}$ & 193 & 104 & 140 & 95 & 73 & 121 & 74 & 80 & 122 & 66 & 78 & 80 & 77 & 97 & 77 & 87 & 74 \\
\hline $\mathrm{Ba}$ & 1210 & 1135 & 1962 & 778 & 508 & 574 & 981 & 1213 & 980 & 623 & 680 & 690 & 725 & 708 & 655 & 1129 & 546 \\
\hline $\mathrm{Sr}$ & 706 & 574 & 733 & 723 & 642 & 669 & 1143 & 863 & 951 & 989 & 775 & 802 & 710 & 735 & 860 & 798 & 740 \\
\hline $\mathrm{Nb}$ & 25 & 35 & 30 & 19 & 21 & 22 & 15 & 12 & 9 & 15 & 14 & 13 & 13 & 14 & 12 & 10 & 9 \\
\hline $\mathrm{Zr}$ & 257 & 208 & 190 & 127 & 154 & 228 & 178 & 131 & 164 & 171 & 156 & 143 & 125 & 128 & 136 & 105 & 123 \\
\hline $\mathrm{Y}$ & 18 & 37 & 22 & 26 & 21 & 18 & 14 & 12 & 16 & 20 & 15 & 13 & 13 & 13 & 17 & 15 & 12 \\
\hline $\mathrm{La}$ & 65 & 58 & 44 & 42 & 55 & 48 & 44 & 36 & 50 & 53 & 27 & 23 & 30 & 27 & 33 & 27 & 28 \\
\hline $\mathrm{Ce}$ & 153 & 134 & 96 & 74 & 98 & 92 & 66 & 63 & 105 & 80 & 66 & 52 & 61 & 60 & 63 & 49 & 50 \\
\hline $\mathrm{Th}$ & 25 & & 19 & & & & & & & & & & & & & & \\
\hline $\mathrm{Pb}$ & 32 & & 34 & & & & & & & & & & & & & & \\
\hline $\mathrm{Rb} / \mathrm{Sr}$ & 0.27 & 0.18 & 0.19 & 0.13 & 0.11 & 0.18 & 0.06 & 0.09 & 0.13 & 0.07 & 0.10 & 0.10 & 0.11 & 0.13 & 0.09 & 0.11 & 0.10 \\
\hline
\end{tabular}

$\mathrm{Fe}_{2} \mathrm{O}_{3} \mathrm{t}$, total iron as ferric iron; blanks, not analyzed.

* MME-M, Monzonitic mafic microgranular enclaves; MME-T, Dioritic to tonalitic mafic microgranular enclaves; HBTon, Hornblende-biotite tonalite; HBGd, Hornblende-biotite granodiorite; BGd, Biotite granodiorite; TMG, Two-mica granodiorite to granite; LGG, Leucogranite; AP, Aplites and Pegmatites; DGb, Diorite and gabbro.

\subsection{Tonalite, hornblende-biotite granodiorite, and biotite granodiorite}

Tonalites and granodiorites are described together because they share many common petrographic features. They are mainly medium-grained rocks, although some micro-granular to granophyric textures are also present. An oriented fabric is common, affecting about three-quarters of the examined samples. Mafic constituents are represented by biotite and hornblende with biotite prevailing over hornblende. Felsic constituents are quartz, plagioclase and Kfeldspar. Characteristic euhedral epidote crystals are always present, sometimes rimming allanite. Titanite, apatite, zircon and opaque minerals, mostly magnetite and ilmenomagnetite, occur as accessories. The biotite granodiorite does not contain hornblende, and is finergrained and often lighter in colour than the tonalite and hornblende-biotite granodiorite.

\subsection{Mafic microgranular enclaves}

Rounded or elongated mafic microgranular enclaves are enclosed within tonalite and granodiorites. They can be split into a monzonitic and a dioritic-tonalitic group (Fig. 3). This distinction is reflected by the enclave size: the monzonitic enclaves range from 26 to $130 \mathrm{~cm}^{3}$, whereas the tonalitic ones are much smaller ranging between 4 and $10 \mathrm{~cm}^{3}$ (Perugini et al., 2003).

No significant differences are observed between the mineral assemblages of the two enclave groups. Moreover, they are quite similar to those of the corresponding host rocks, although mafic minerals (mainly biotite, \pm hornblende) and epidote are more abundant in the enclaves. Relatively common accessory minerals are acicular apatite and titanite; zircon and allanite are less frequent.

Usually, megacrysts of plagioclase and K-feldspar and rarely of biotite and hornblende can be seen within the enclaves, captured from the host rocks (Perugini 


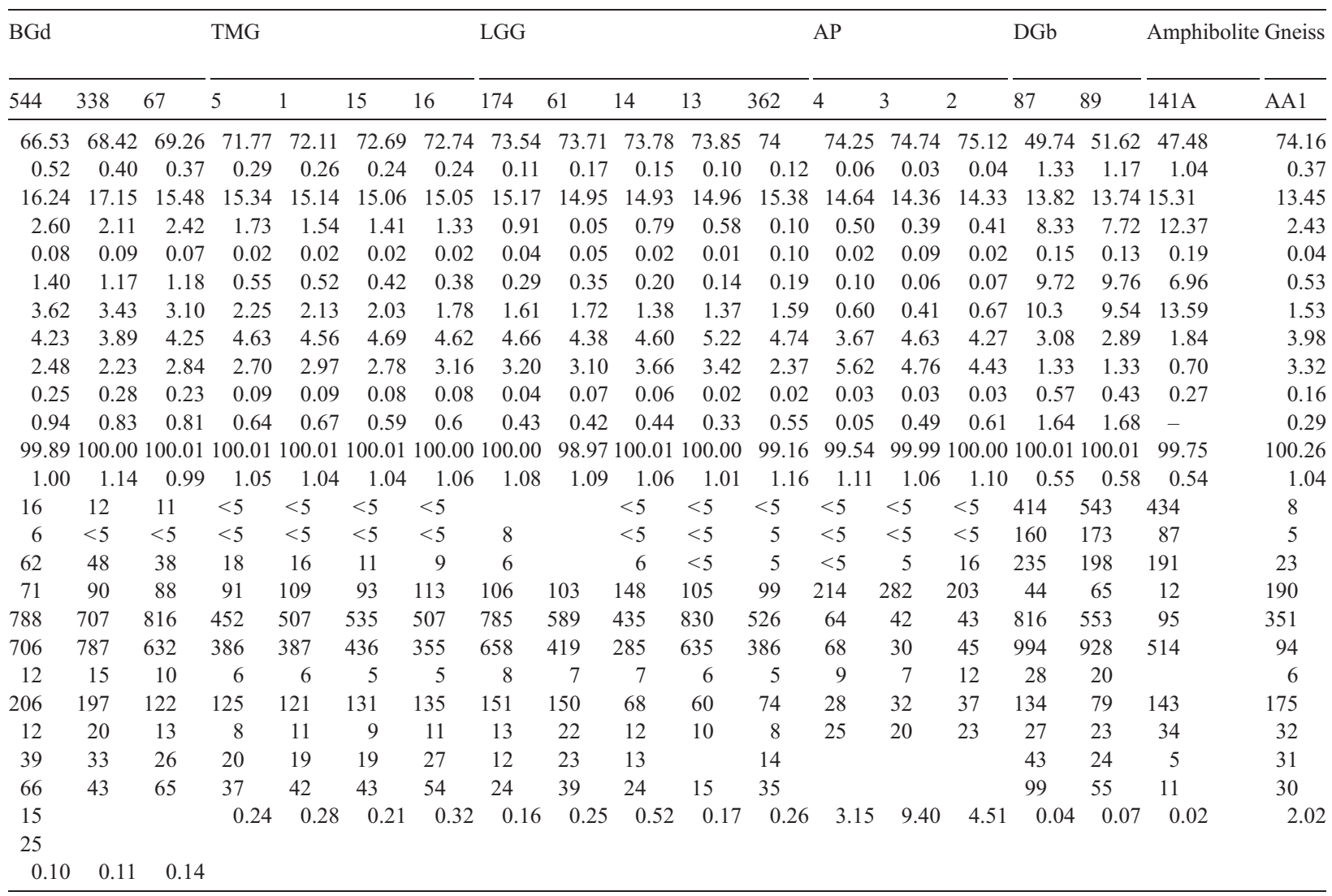

et al., 2003). In some cases feldspar xenocrysts crosscut the enclave/host boundary. These features, common in enclaves world-wide, are considered to prove a liquid state of the enclaves upon their incorporation into the more felsic magma (e.g. Vernon, 1984; Castro et al., 1991; Perugini et al., 2003).

\subsection{Two-mica granodiorite to granite and leucogranite}

The two-mica granodiorite to granite (hereafter twomica granite) and the leucogranite are discussed together due to their similar mineralogy, although they display some modal and textural differences (D'Amico et al., 1990). Generally, the two-mica granite is fine-to medium-grained, whereas the leucogranite is usually coarser-grained. They contain quartz, microcline, plagioclase, biotite, and muscovite. Discrete masses of leucogranite have microcline megacrysts which originate a porphyritic texture. Scarce accessory minerals are opaques (mostly ilmenite), apatite, zircon and locally epidote, the latter present in the two-mica granite only.

\subsection{Aplites and pegmatites}

The aplites and pegmatites consist of quartz, K-feldspar, plagioclase and muscovite and subordinate amounts of biotite and garnet. Regarding aplites, those cutting the granodiorites contain biotite and little muscovite, whereas those cutting the granites are muscovite-rich and biotitepoor (Tsilibari and Eleftheriadis, 1989).

\subsection{Diorite and gabbro}

These rocks, often altered, are medium-to coarsegrained meta-diorite and meta-gabbro. In some parts they show banding expressed by differences in grain size and mineralogy, possibly suggesting a cumulate nature. Effects of pervasive metasomatism are indicated by 
Table 3

Rare earth element analyses of representative SPC rocks

\begin{tabular}{|c|c|c|c|c|c|c|c|c|c|c|c|c|c|c|c|c|c|}
\hline Sample & Rock type * & $\mathrm{La}$ & $\mathrm{Ce}$ & $\mathrm{Nd}$ & $\mathrm{Sm}$ & $\mathrm{Eu}$ & $\mathrm{Gd}$ & Dy & Ho & Er & $\mathrm{Yb}$ & $\mathrm{Lu}$ & $(\mathrm{La} / \mathrm{Sm})_{\mathrm{CN}}$ & $(\mathrm{La} / \mathrm{Yb})_{\mathrm{CN}}$ & $(\mathrm{Gd} / \mathrm{Yb})_{\mathrm{CN}}$ & $\mathrm{Eu} / \mathrm{Eu} *$ & $\sum$ REE \\
\hline 83 & MME-M & 77 & 142 & 56 & 9.3 & 1.7 & 5.4 & 5.1 & 0.84 & 2.4 & 2.6 & 0.35 & 4.6 & 18 & 0.80 & 0.66 & 303 \\
\hline 310 & MME-T & 52 & 94 & 40 & 6.4 & 1.4 & 3.4 & 3.1 & 0.46 & 1.3 & 1.4 & 0.18 & 4.5 & 23 & 0.94 & 0.85 & 204 \\
\hline 137 & HBTon & 72 & 127 & 45 & 6.1 & 1.4 & 2.8 & 2.5 & 0.41 & 0.87 & 0.91 & 0.10 & 6.5 & 48 & 1.2 & 0.87 & 259 \\
\hline 121 & HBTon & 42 & 78 & 30 & 4.5 & 0.93 & 1.9 & 2.1 & 0.31 & 0.85 & 0.81 & 0.09 & 5.2 & 32 & 0.98 & 0.83 & 161 \\
\hline 63 & HBTon & 67 & 121 & 43 & 6.0 & 1.2 & 2.6 & 2.5 & 0.38 & 0.91 & 0.94 & 0.11 & 6.1 & 43 & 1.1 & 0.78 & 245 \\
\hline 139 & HBTon & 54 & 98 & 39 & 6.2 & 1.3 & 3.2 & 3.2 & 0.51 & 1.3 & 1.3 & 0.15 & 4.7 & 26 & 1.0 & 0.82 & 207 \\
\hline 9 & HBTon & 32 & 60 & 24 & 4.0 & 0.97 & 1.9 & 1.9 & 0.34 & 0.84 & 0.8 & 0.10 & 4.4 & 24 & 0.95 & 0.95 & 127 \\
\hline 7 & HBGd & 38 & 69 & 26 & 3.8 & 0.88 & 1.6 & 1.7 & 0.27 & 0.71 & 0.74 & 0.10 & 5.5 & 31 & 0.90 & 0.93 & 143 \\
\hline 6 & HBGd & 40 & 72 & 26 & 3.8 & 0.85 & 1.6 & 1.7 & 0.29 & 0.68 & 0.71 & 0.10 & 5.8 & 34 & 0.92 & 0.90 & 148 \\
\hline 12 & HBGd & 41 & 72 & 26 & 3.7 & 0.8 & 1.4 & 1.6 & 0.26 & 0.67 & 0.7 & 0.10 & 6.0 & 35 & 0.86 & 0.89 & 148 \\
\hline 8 & HBGd & 34 & 60 & 22 & 3.3 & 0.75 & 1.4 & 1.5 & 0.25 & 0.65 & 0.64 & 0.10 & 5.6 & 32 & 0.91 & 0.92 & 125 \\
\hline 10 & HBGd & 49 & 88 & 30 & 4.0 & 0.88 & 1.6 & 1.7 & 0.28 & 0.69 & 0.77 & 0.10 & 6.7 & 39 & 0.85 & 0.89 & 177 \\
\hline 11 & HBGd & 36 & 64 & 24 & 3.5 & 0.74 & 1.4 & 1.6 & 0.28 & 0.69 & 0.68 & 0.10 & 5.7 & 32 & 0.85 & 0.87 & 133 \\
\hline 338 & BGd & 42 & 76 & 29 & 4.3 & 0.93 & 2.3 & 2.3 & 0.41 & 1.0 & 0.98 & 0.11 & 5.4 & 26 & 0.94 & 0.82 & 158 \\
\hline 66 & BGd & 33 & 59 & 23 & 3.5 & 0.77 & 2.0 & 2.0 & 0.36 & 0.92 & 0.85 & 0.10 & 5.1 & 23 & 0.94 & 0.81 & 125 \\
\hline 5 & TMG & 21 & 38 & 15 & 2.6 & 0.57 & 0.96 & 1.1 & 0.19 & 0.34 & 0.26 & 0.10 & 4.6 & 49 & 1.6 & 0.92 & 81 \\
\hline 1 & TMG & 24 & 44 & 17 & 2.8 & 0.59 & 1.2 & 1.2 & 0.21 & 0.39 & 0.31 & 0.10 & 4.6 & 47 & 1.5 & 0.84 & 91 \\
\hline 15 & TMG & 25 & 45 & 17 & 2.8 & 0.54 & 1.1 & 0.86 & 0.11 & 0.19 & 0.15 & 0.10 & 4.9 & 101 & 2.5 & 0.79 & 93 \\
\hline 16 & TMG & 28 & 51 & 19 & 2.9 & 0.54 & 1.0 & 0.9 & 0.16 & 0.21 & 0.19 & 0.10 & 5.3 & 91 & 2.0 & 0.77 & 104 \\
\hline 174 & LGG & 11 & 20 & 8.3 & 1.7 & 0.22 & 0.68 & 0.68 & 0.14 & 0.29 & 0.24 & 0.10 & 3.4 & 27 & 1.1 & 0.52 & 43 \\
\hline 61 & LGG & 20 & 37 & 14 & 2.4 & 0.33 & 0.7 & 0.78 & 0.14 & 0.22 & 0.2 & 0.01 & 4.7 & 62 & 1.5 & 0.60 & 77 \\
\hline 14 & LGG & 16 & 28 & 11 & 2.0 & 0.32 & 0.78 & 0.76 & 0.14 & 0.25 & 0.19 & 0.10 & 4.3 & 50 & 1.6 & 0.66 & 59 \\
\hline 13 & LGG & 9.2 & 18 & 7.9 & 1.8 & 0.26 & 0.65 & 0.73 & 0.14 & 0.27 & 0.25 & 0.10 & 2.8 & 22 & 1.1 & 0.61 & 39 \\
\hline 362 & LGG & 20 & 35 & 13 & 2.3 & 0.31 & 0.6 & 0.72 & 0.10 & 0.17 & 0.19 & 0.02 & 4.7 & 63 & 1.4 & 0.59 & 73 \\
\hline 4 & $\mathrm{AP}$ & 4 & 8.2 & 3.8 & 1.1 & 0.12 & 0.34 & 0.89 & 0.17 & 0.5 & 0.46 & 0.10 & 2.0 & 5.3 & 0.48 & 0.46 & 20 \\
\hline 3 & $\mathrm{AP}$ & 3 & 6.4 & 3 & 1.1 & 0.10 & 0.64 & 1.7 & 0.32 & 0.92 & 1.0 & 0.12 & 1.5 & 1.7 & 0.40 & 0.34 & 18 \\
\hline 2 & $\mathrm{AP}$ & 4.5 & 9.8 & 4.6 & 1.4 & 0.09 & 0.72 & 1.2 & 0.22 & 0.63 & 0.61 & 0.10 & 1.8 & 4.5 & 0.62 & 0.25 & 24 \\
\hline 87 & $\mathrm{DGb}$ & 55 & 119 & 57 & 9.6 & 2.3 & 5.3 & 4.6 & 0.76 & 1.8 & 1.8 & 0.23 & 3.2 & 19 & 1.1 & 0.90 & 258 \\
\hline 89 & $\mathrm{DGb}$ & 32 & 70 & 37 & 6.7 & 1.5 & 3.9 & 3.5 & 0.57 & 1.5 & 1.4 & 0.18 & 2.6 & 14 & 1.0 & 0.84 & 157 \\
\hline $141 \mathrm{~A}$ & Amphibolite & 1.9 & 4.7 & 4.9 & 1.7 & 0.59 & 2.1 & 4.0 & 0.89 & 3.0 & 3.0 & 0.44 & 0.61 & 0.38 & 0.39 & 0.96 & 27 \\
\hline AA1 & Gneiss & 29 & 61 & 30 & 6.5 & 0.65 & 3.7 & 3.3 & 0.44 & 1.0 & 0.76 & 0.08 & 2.4 & 23 & 1.8 & 0.37 & 136 \\
\hline
\end{tabular}

Normalization values after Haskin et al. (1966).

* MME-M, Monzonitic mafic microgranular enclaves; MME-T, Dioritic to tonalitic mafic microgranular enclaves; HBTon, Hornblende-biotite tonalite; HBGd, Hornblende-biotite granodiorite; BGd, Biotite granodiorite; TMG, Two-mica granodiorite to granite; LGG, Leucogranite; AP, Aplites and Pegmatites; DGb, Diorite and gabbro.

albitization of plagioclase and transformation of clinopyroxene into tremolite. Scarce amounts of biotite, Kfeldspar and quartz are also present. Titanite, apatite, and opaque minerals constitute accessory phases.

\section{Mineral chemistry}

Plagioclase and K-feldspar coexist in all rock types. Plagioclase is generally mildly or strongly zoned with normal, reverse, and oscillatory zoning. The last two zonings, typically interrupted by several resorption zones, are found in the more basic rocks. The composition of plagioclase ranges from $\mathrm{An}_{51}-\mathrm{An}_{12}$ in enclaves, $\mathrm{An}_{46}$ $\mathrm{An}_{14}$ in tonalite, $\mathrm{An}_{30}-\mathrm{An}_{22}$ in hornblende-biotite granodiorite, $\mathrm{An}_{26}-\mathrm{An}_{22}$ in biotite granodiorite, $\mathrm{An}_{34}-$ $\mathrm{An}_{10}$ in two-mica granite, and $\mathrm{An}_{27}-\mathrm{An}_{8}$ in leucogranite. Orthoclase content does not exceed $\mathrm{Or}_{2}$.
Perthitic K-feldspar (maximum to intermediate microcline) occurs as subhedral to anhedral interstitial crystals in all rock types, and also as megacrysts in the leucogranites. Plagioclase is the most abundant mineral inclusion, mostly arranged parallel to possible faces of the host K-feldspar. The composition of the K-feldspar ranges between $\mathrm{Or}_{84}$ and $\mathrm{Or}_{96}$, with the anorthite component not exceeding 1\%. Barium content is higher in megacrysts $\left(\mathrm{Cs}_{2-3.5}\right)$ than in the matrix $\mathrm{K}$-feldspar.

Amphibole occurs as subhedral to anhedral prismatic crystals commonly inter-grown with biotite. Irregularly shaped grains, apparently due to resorption, are also observed in the tonalite and the hornblende-biotite granodiorite. The amount of amphibole decreases as silica contents of host rock increase and with the decrease of the modal plagioclase. Amphibole is magnesiohornblende and edenite (Leake et al., 2003) rich in 


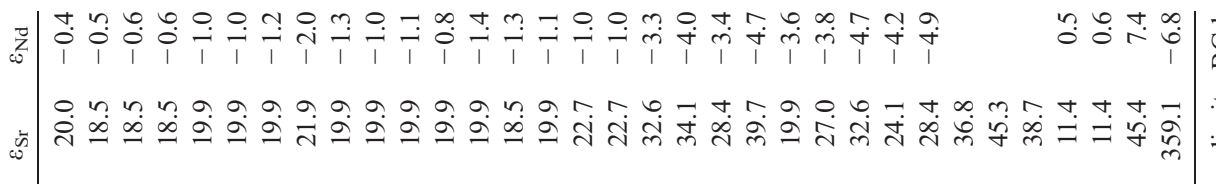

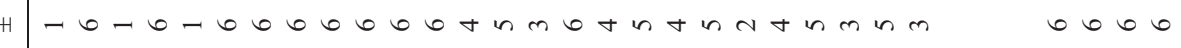

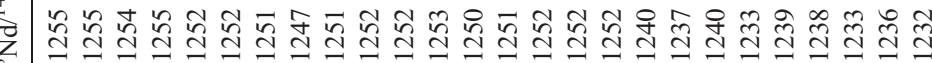

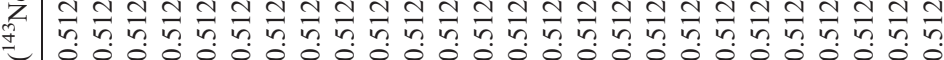

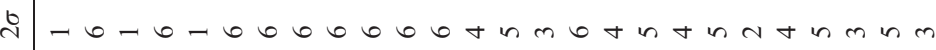

ra

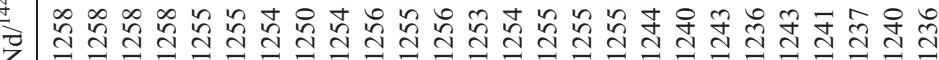

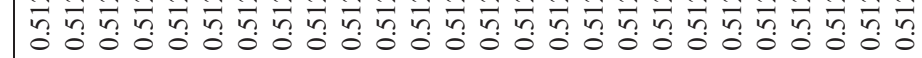

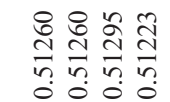

$\circ 660$

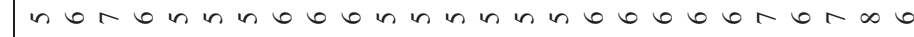

迅

जี

oก 2

$\bar{z}$

है

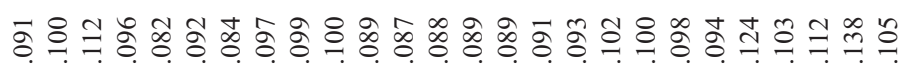

응으응

$\circ \dot{0} 00$

$\bar{z}$

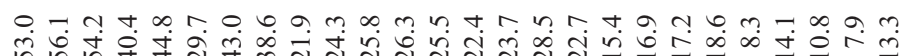

$\infty<0,0$

ம்

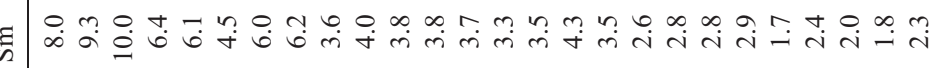

ํํ의

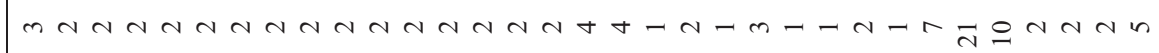

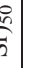

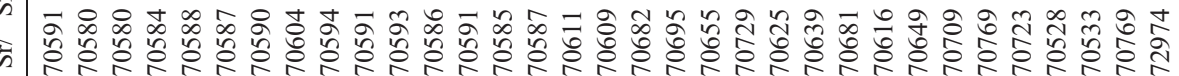

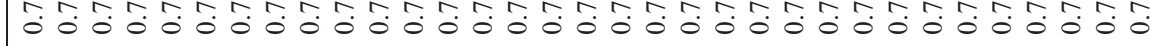

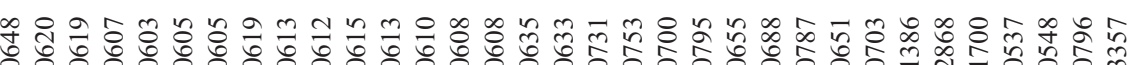

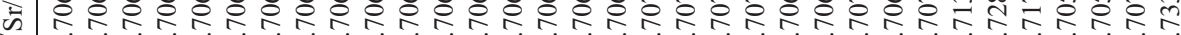

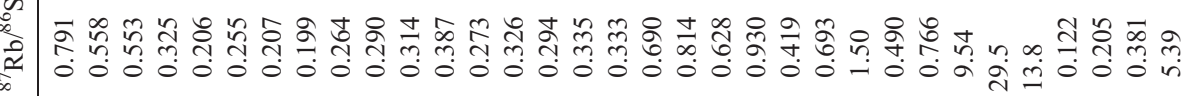

产总

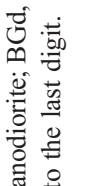

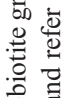


alumina and relatively poor in titanium (Table 1). The $\mathrm{Mg} /\left(\mathrm{Mg}+\mathrm{Fe}^{2+}\right)$ ratio changes little between 0.52 and 0.66. The hornblende geobarometer of Schmidt (1992) used for the Sithonia amphiboles, gives crystallization pressures of 3.7-4.1 Kbar for enclaves, 3.9-4.9 for tonalite, and 3.9-5.2 for hornblende-biotite granodiorite. Considering errors (ca. \pm 0.6 Kbar), all rock types can be considered to have crystallized at ca. the same pressure (i.e. 5.0 Kbar). The presence of primary epidote (Christofides and Eleftheriadis, 1992) agrees with such relatively high pressures (e.g. Zen and Hammarstrom, 1984; Vyhnal et al., 1991).
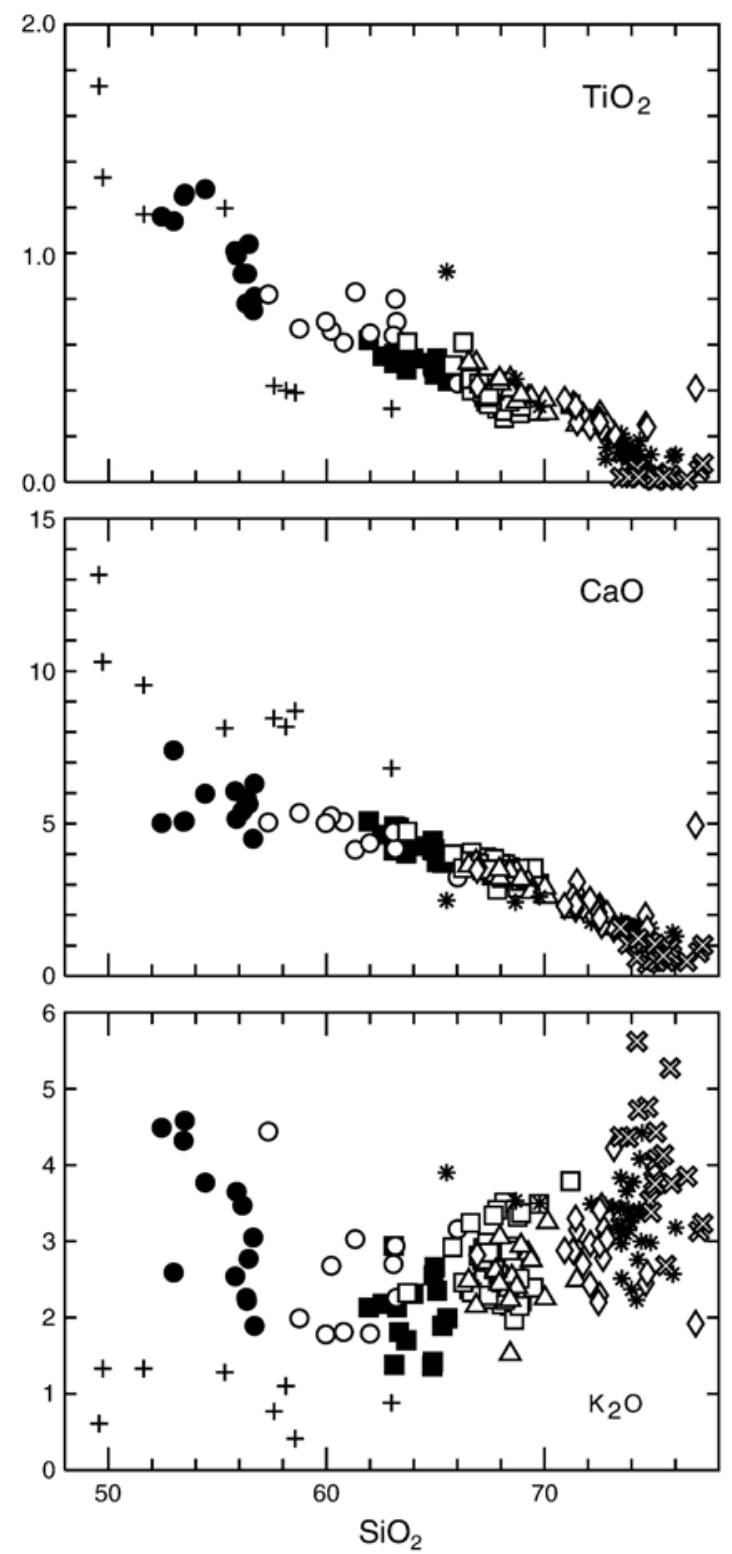

Biotite is the most abundant ferromagnesian mineral in the SPC, associated either with hornblende in enclaves, tonalite and hornblende-biotite granodiorite, or with muscovite in two-mica granite and leucogranite. Two groups of biotite are distinguished, a Mg-rich group including biotites coexisting with hornblende, and a Ferich group comprising those associated with muscovite. Biotites of biotite granodiorite show intermediate compositions, whereas those from leucogranite are generally the richest in $\mathrm{Fe}^{2+}$ (Table 1). The chemistry and compositional variations (major and trace elements) of both hornblende and biotite were investigated by
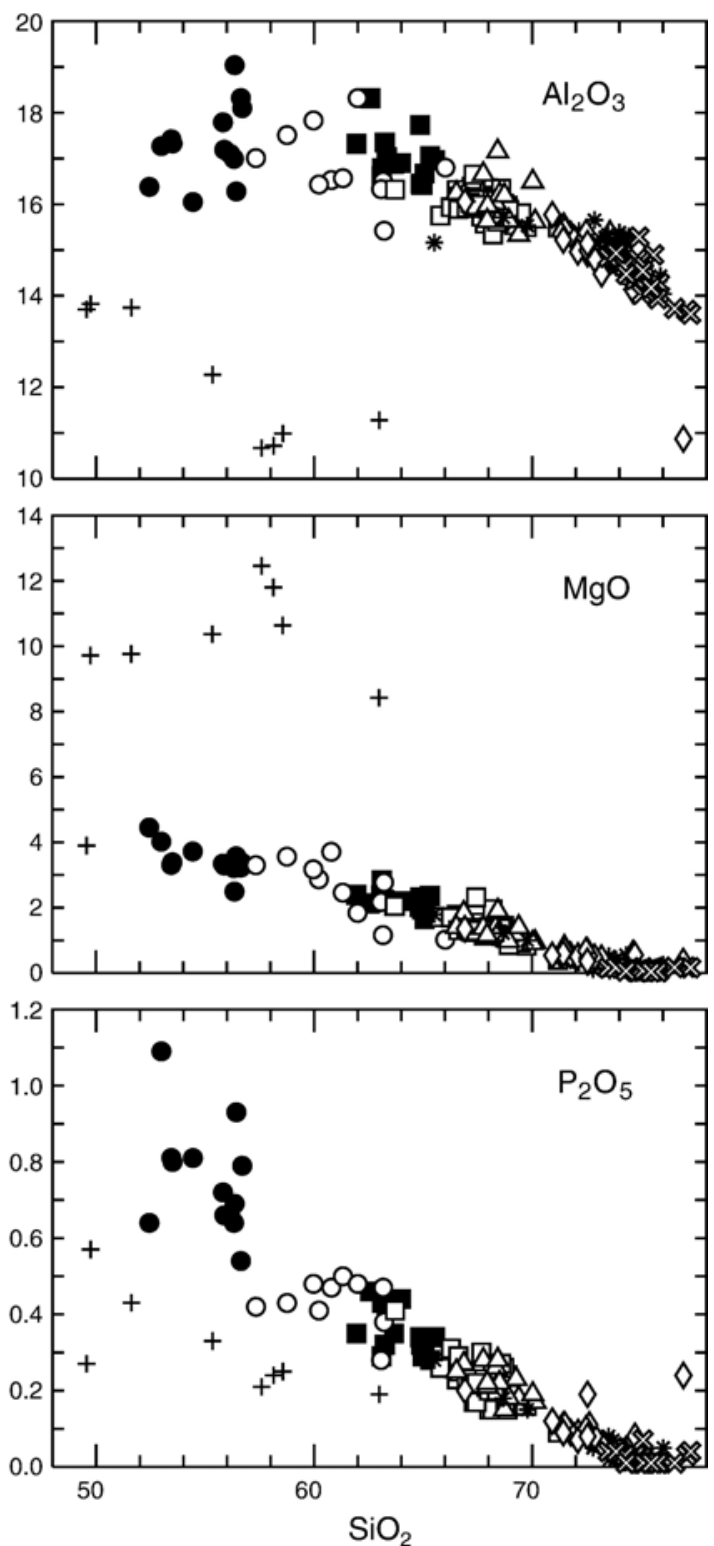

Fig. 4. Selected major element vs. $\mathrm{SiO}_{2}$ (wt.\%) diagrams for the SPC rocks. Symbols as in Fig. 3. 

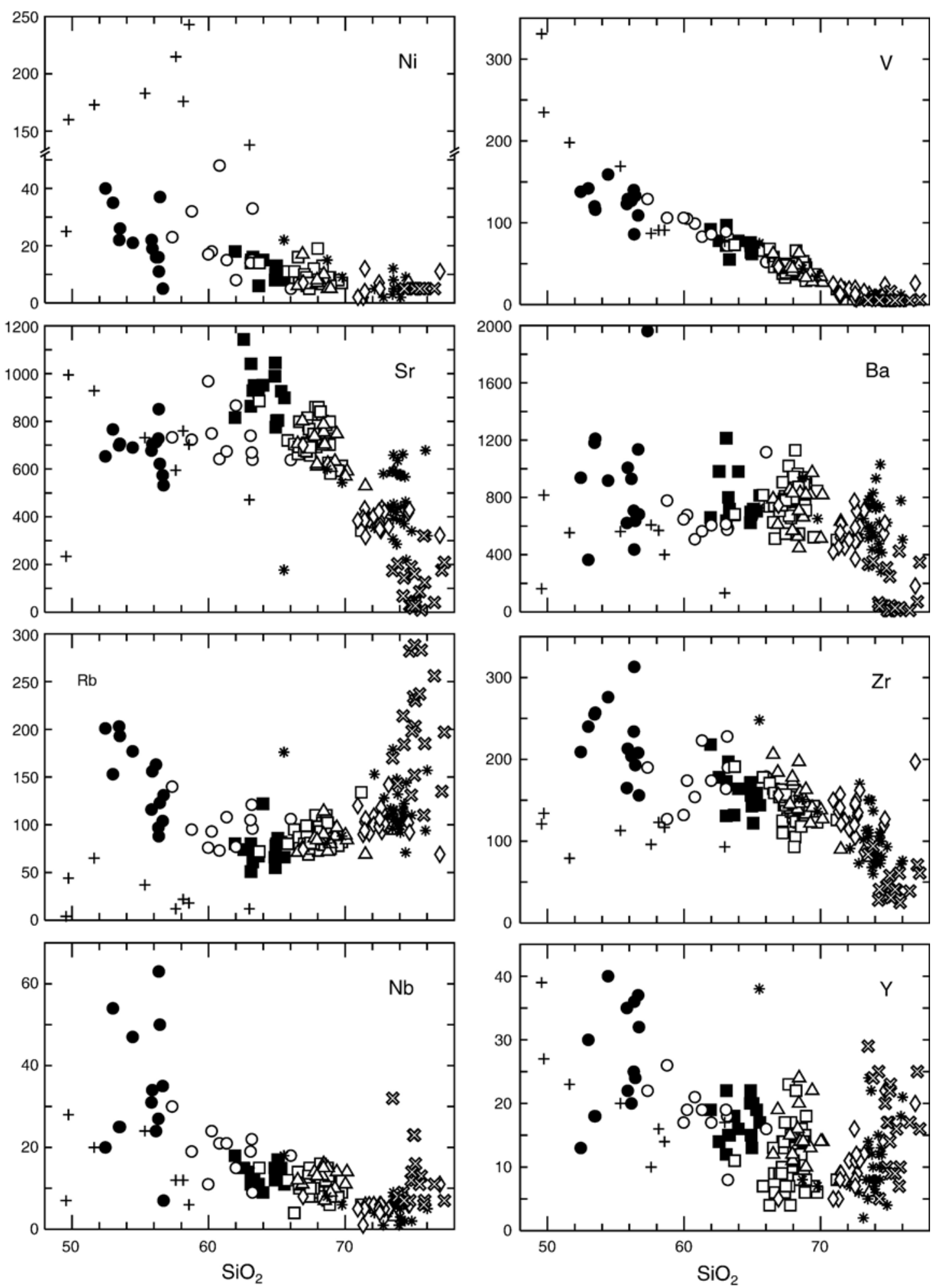

Fig. 5. Selected trace element (ppm) vs. $\mathrm{SiO}_{2}$ (wt.\%) diagrams for the SPC rocks. Symbols as in Fig. 3. 

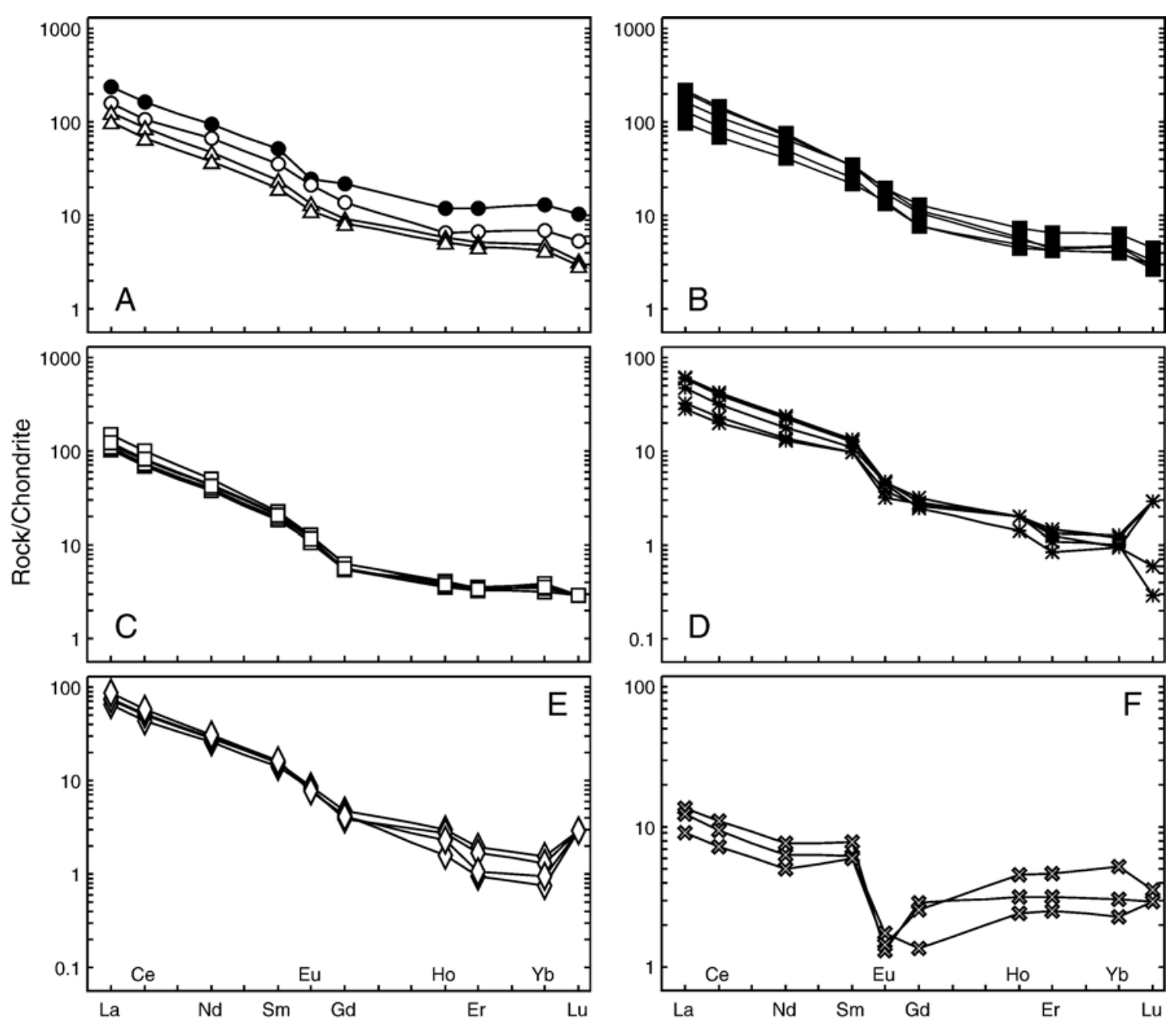

Fig. 6. Chondrite-normalized (Haskin et al., 1966) REE patterns for the SPC rocks. A) MME-M, MME-T, and biotite granodiorite; B) hornblendebiotite tonalite; C) hornblende-biotite granodiorite; D) leucogranite; E) two-mica granodiorite to granite; F) aplites and pegmatites. Symbols as in Fig. 3.

Christofides et al. (1998). Based on the distribution coefficient $K_{\mathrm{D}}=\left(X_{\mathrm{Mg}} / X_{\mathrm{Fe}}\right)_{\mathrm{Bi}} /\left(X_{\mathrm{Mg}} / X_{\mathrm{Fe}}\right)_{\mathrm{Hb}}$ values of coexisting biotite-amphibole pairs (1.02 to 1.24), these biotites are considered to having formed by replacement of amphibole at the magmatic state (e.g. Speer, 1987).

Three types of muscovite, primary, late to post-magmatic, and secondary (sericite on plagioclase) are recognised on the basis of their mode of occurrence and $\mathrm{TiO}_{2}$ content (Table 1). Large flakes and lath-shaped crystals, occurring singly, in clusters, or inter-grown with biotite, have characteristics favouring a primary origin (e.g. Miller et al., 1981). Large flakes, resembling those of primary muscovite except for being slightly coloured and replacing feldspar are suggested to be of secondary origin.
Epidote is present mostly in the enclaves, tonalite and granodiorites, occurring sometimes as euhedral crystals which, along with some textural relationships, favours a primary origin (Christofides and Eleftheriadis, 1992; Perugini et al., 2003). Allanite occurs either as individual stout prismatic or elongated, euhedral or rounded crystals, or as cores rimmed by epidote.

Opaque minerals are mostly magnetite and ilmenomagnetite, which are more abundant in tonalite and granodiorites, and secondary ilmenite, more abundant in granites.

\section{Whole-rock geochemistry}

More than 140 samples from SPC were analyzed for major and trace elements. REE analyses were carried out 
on 30 representative samples, and thirty-one and twentyeight samples were analyzed for $\mathrm{Sr}$ and $\mathrm{Nd}$ isotopes, respectively. Representative analyses for each rock type are listed in Tables 2-4; analytical details are given in the Appendix.

\subsection{Major elements}

The rocks of SPC have compositions similar to the calc-alkaline series, with $\mathrm{Na}_{2} \mathrm{O} / \mathrm{K}_{2} \mathrm{O}$ ratio up to 3.2. Alumina-saturation index $\left[\mathrm{ASI}=\mathrm{Al}_{2} \mathrm{O}_{3} /\left(\mathrm{CaO}+\mathrm{Na}_{2} \mathrm{O}+\right.\right.$ $\mathrm{K}_{2} \mathrm{O}$ ) molar] increases with $\mathrm{SiO}_{2}$; enclaves are metaluminous (ASI $=0.77-0.98)$, tonalite, hornblende-biotite granodiorite, and biotite granodiorite are mostly metaluminous, with a few samples showing a slightly peraluminous character $(0.90-1.16)$. The same holds for two-mica granite and leucogranite (0.98-1.17). Aplites and pegmatites reach the highest values of the alumina-saturation index (up to 1.28).

As a whole, the SPC varies more or less continuously in chemical composition from enclaves through the tonalite to leucogranite and aplites/pegmatites. $\mathrm{TiO}_{2}$,
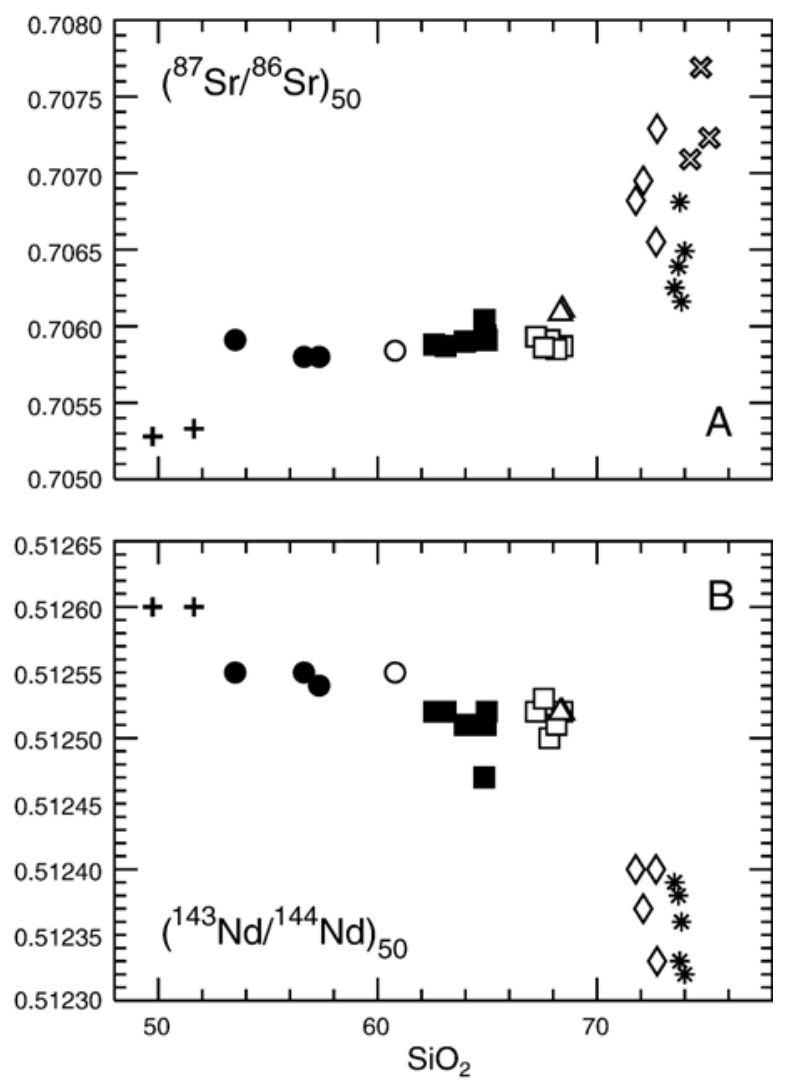

Fig. 7. $\left({ }^{87} \mathrm{Sr} /{ }^{86} \mathrm{Sr}\right)_{50}$ and $\left({ }^{143} \mathrm{Nd} /{ }^{144} \mathrm{Nd}\right)_{50}$ vs. $\mathrm{SiO}_{2}$ (wt.\%) diagrams for the SPC rocks. Symbols as in Fig. 3.

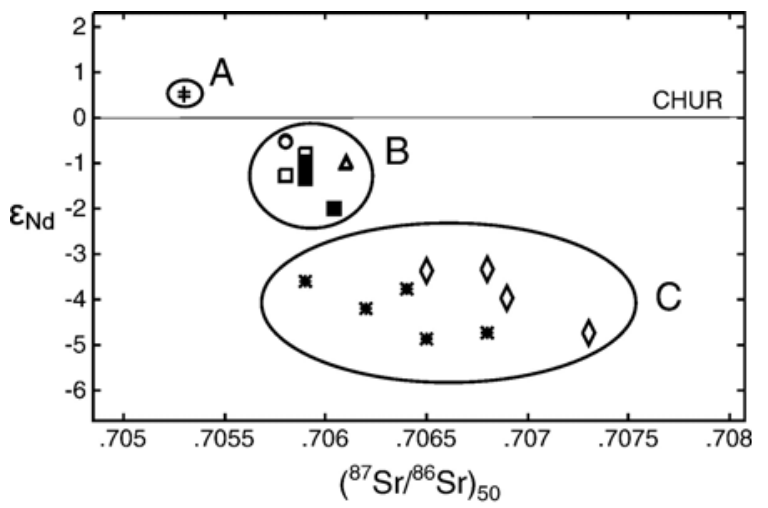

Fig. $8 .\left({ }^{87} \mathrm{Sr} /{ }^{86} \mathrm{Sr}\right)_{50}$ vs. $\varepsilon_{\mathrm{Sr}}$ for the SPC rocks. Symbols as in Fig. 3. Labels in the graph are as follow: A) diorite and gabbro group; B) enclaves, tonalite, hornblende-biotite granodiorite and biotite granodiorite group; C) two-mica granite and leucogranite group.

$\mathrm{Al}_{2} \mathrm{O}_{3}, \mathrm{Fe}_{2} \mathrm{O}_{3}$ tot (not shown), $\mathrm{MgO}, \mathrm{CaO}$ and $\mathrm{P}_{2} \mathrm{O}_{5}$ display negative linear correlation with $\mathrm{SiO}_{2}$ (Fig. 4), although with some scatter. The $\mathrm{K}_{2} \mathrm{O}$ decreases with increasing $\mathrm{SiO}_{2}$ in the monzonitic enclaves and then increases slightly from the tonalitic enclaves to the biotite granodiorite, whereas it is highly scattered in the two-mica granite, leucogranite, and aplites and pegmatites. $\mathrm{Na}_{2} \mathrm{O}$ (not shown) is very scattered in all rock types. The compositional variations of the diorites and gabbros differ significantly from the rest of the pluton: some major-element oxides (e.g. $\mathrm{Al}_{2} \mathrm{O}_{3}, \mathrm{CaO}, \mathrm{MgO}, \mathrm{K}_{2} \mathrm{O}$, $\mathrm{P}_{2} \mathrm{O}_{5}$ ) plot far away from the main trends of all the other rock types, and only $\mathrm{TiO}_{2}$ and $\mathrm{Fe}_{2} \mathrm{O}_{3}$ tot are aligned with the other samples.

\subsection{Trace elements}

Among ferromagnesian elements, $\mathrm{Ni}$ and $\mathrm{Cr}$ (not shown) are rather scattered, whereas $\mathrm{V}$ shows a nearly linear decrease from the monzonitic enclaves to the twomica granite and leucogranite (Fig. 5). Sr increases from the enclaves to the tonalite and then it drops sharply towards the aplites and pegmatites, with some leucogranite samples deviating slightly from the main trend. Although with some scatter, Ba abundances are similar in both types of enclaves and tonalites, and then decrease towards the aplites and pegmatites. $\mathrm{Rb}$ variation is $\mathrm{U}$-shaped, decreasing from the enclaves to the tonalite, increasing slightly up to the biotite granodiorite, and then increasing abruptly up to the aplites and pegmatites. $\mathrm{Zr}$ shows a broad negative correlation with $\mathrm{SiO}_{2}$ across all rock types, with some scatter. $\mathrm{Nb}$ is scattered in the monzonitic enclaves and decreases from the tonalitic enclaves to the two-mica granite and leucogranite, with most aplites and pegmatites showing typical enrichment in this element (e.g. Poli, 
1992). $\mathrm{Y}$ is rather scattered in all rock types. The ratio of $\mathrm{Rb} / \mathrm{Sr}$ decreases from the monzonitic enclaves $(0.31-0.10)$ to the tonalite $(0.05-0.13)$ and then increases up to the twomica granite and leucogranite $(0.14-0.66)$ with aplites and pegmatites having extremely high values $(0.35-32)$. Regarding diorite and gabbro, their relationships with other samples are quite variable, with some elements plotting along the main trends (e.g. V, Ba, Y) and other elements strongly deviating (e.g. $\mathrm{Ni}, \mathrm{Rb}, \mathrm{Nb}$ ).

\subsection{Rare Earth Elements (REE)}

Chondrite-normalized REE patterns are reported in Fig. 6. Differences between samples are most pronounced in LREE abundances $\left(\mathrm{La}_{\mathrm{N}}=27-233\right)$ and the degree of fractionation of HREE $\left(\mathrm{Gd}_{\mathrm{N}} / \mathrm{Yb}_{\mathrm{N}}=1.6-5.6\right)$. LREE are enriched relative to HREE in all rocks (La/ $\mathrm{Yb}_{\mathrm{N}}=20-113$ ), and $\Sigma$ REE decreases from the enclaves to the two-mica granite and leucogranite with gabbro and diorite deviating from the main trend (Table 3 ). In the tonalitic enclaves, tonalite, hornblende-biotite granodiorite, biotite granodiorite and the two-mica granite, the $\mathrm{Eu}$ anomaly is small $\left(\mathrm{Eu} / \mathrm{Eu}^{*}=0.98-0.80\right)$ and remains almost constant with increasing silica content. The monzonitic enclaves $\left(\mathrm{Eu} / \mathrm{Eu}^{*}=0.69\right)$ and the leucogranite $\left(\mathrm{Eu} / \mathrm{Eu}^{*}=0.60\right)$ have higher Eu anomaly. The aplites and pegmatites show quite different patterns, being much depleted in LREE, enriched in HREE relative to leucogranites, and showing a very pronounced $\mathrm{Eu}$ anomaly (Eu/Eu* as low as 0.2$)$.

\section{4. $\mathrm{Sr}$ and Nd isotopes}

The $\mathrm{Sr}$ and $\mathrm{Nd}$ initial ratios were age-corrected to $50 \mathrm{Ma}$ (Christofides et al., 1990), and data are given in Table 4. The diorite and gabbro group has the lowest $\left({ }^{87} \mathrm{Sr} /{ }^{86} \mathrm{Sr}\right)_{50}$ value $(0.70528)$. The $\mathrm{Sr}$ isotopic ratio $\left({ }^{87} \mathrm{Sr} /{ }^{86} \mathrm{Sr}\right)_{50}$ increases slightly with silica, with a trend from the enclaves through tonalite and hornblendebiotite granodiorite to biotite granodiorite (Fig. 7A), ranging between 0.70580 (enclaves) and 0.70611 (biotite granodiorite). In contrast, in the granites, aplites and pegmatites the $\left({ }^{87} \mathrm{Sr} /{ }^{86} \mathrm{Sr}\right)_{50}$ ratio shows a larger variation, increasing from 0.70616 (leucogranite) to 0.70769 (aplites and pegmatites) for comparable range of silica content. The $\left({ }^{143} \mathrm{Nd} /{ }^{144} \mathrm{Nd}\right)_{50}$ ratio in the diorite and gabbro group is the highest (0.51260) and shows quite constant values in the enclaves, tonalite, hornblendebiotite granodiorite and biotite granodiorite around 0.51252 . In the granites the $\left({ }^{143} \mathrm{Nd} /{ }^{144} \mathrm{Nd}\right)_{50}$ ratio is lower, ranging between 0.51232 (leucogranite) and 0.51240 (two-mica granite) (Fig. 7B).
The $\varepsilon_{\mathrm{Nd}}$ Vs. $\left({ }^{87} \mathrm{Sr} /{ }^{86} \mathrm{Sr}\right)_{50}$ diagram (Fig. 8) distinguishes three different rock groups: i) the diorite and gabbro group (A), ii) the enclaves, tonalite, hornblende-biotite granodiorite and biotite granodiorite group (B), and iii) the twomica granite and leucogranite group $(\mathrm{C})$. The first group is homogenous with $\left({ }^{87} \mathrm{Sr} /{ }^{86} \mathrm{Sr}\right)_{50}=0.70530$ and $\varepsilon_{\mathrm{Nd}}=-0.5$ to -0.6 ; the second group, which is relatively homogenous with $\left({ }^{87} \mathrm{Sr} /{ }^{86} \mathrm{Sr}\right)_{50}=0.70580$ to 0.70604 and $\varepsilon_{\mathrm{Nd}}=-0.5$ to -2.0 , has low $\varepsilon_{\mathrm{Nd}}$ values and slightly elevated $\left({ }^{87} \mathrm{Sr} /{ }^{86} \mathrm{Sr}\right)_{50}$ values; the third group shows higher $\left({ }^{87} \mathrm{Sr} /{ }^{86} \mathrm{Sr}\right)_{50}$ values and lower $\varepsilon_{\mathrm{Nd}}$ values, with the leucogranite having, on average, lower $\left({ }^{87} \mathrm{Sr} /{ }^{86} \mathrm{Sr}\right)_{50}$.

As shown by geochemistry, the diorite and gabbro samples differ significantly from those forming the rest of the pluton; in binary plots of various geochemical parameters are highly scattered and separated from the general trend of the pluton (e.g. $\mathrm{MgO}, \mathrm{Al}_{2} \mathrm{O}_{3}, \mathrm{Ni}, \mathrm{Rb}$, and isotopes). Most of these geochemical features, together with textural characteristics, are consistent with an idea that these rocks cannot be considered to represent true liquids, i.e. are cumulates. Besides they have been affected by pervasive metasomatism and weathering. Therefore, they can be hardly used to understand genesis and evolution of the other rock types, and they will be not further considered in the rest of this work.

\section{Discussion}

The Sithonia plutonism can be divided into two main intrusive phases. The first one, more evolved, is represented by the two-mica granite and leucogranite (hereafter acid group) whereas the second one, less evolved, includes the tonalite, hornblende-biotite granodiorite, biotite granodiorite, and their mafic microgranular enclaves (hereafter basic group). Relative percentage of the two groups in outcrop is about $60 \%$ and $40 \%$, respectively.

Field evidence shows that the leucogranite cuts the two-mica granite with sharp contacts, indicating that the latter behaved as a rheologically solid body during the intrusion of the leucogranite mass. The leucogranite also intrudes the hornblende-biotite granodiorite; the latter occurs within the leucogranite as plastically deformed masses. This shows that, at the time of intrusion, the hornblende-biotite granodiorite was still behaving as a rheologically plastic body. The central part of the hornblende-biotite granodiorite is intruded by a finer-grained biotite granodiorite with sharp contacts. Scattered masses of tonalite pass gradually into the surrounding hornblende-biotite granodiorite. These features are consistent with geochronological data, slightly older for the two-mica granite (ca. $50 \mathrm{Ma}$ on average) but similar for 
the leucogranite, hornblende-biotite granodiorite, tonalite and biotite granodiorite (ca. $46 \mathrm{Ma}$; Christofides et al., 1990). Therefore, distinct magmas with different degrees of evolution seem to have coexisted in the area at about 46-50 Ma.

Macroscopic and petrographic characteristics of the tonalite, hornblende-biotite granodiorite, and biotite granodiorite are consistent with a genesis where magma interaction processes played a major role. This idea is supported by the occurrence of mafic microgranular enclaves and disequilibrium phenomena common in most mineralogical phases of both the enclaves and the host rocks. The presence of the mafic microgranular enclaves is a clear evidence of magma interaction since they are interpreted as relics of the original mafic magma that survived the mixing process (e.g. Didier and Barbarin, 1991; Perugini et al., 2003). Besides, the occurrence of xenocrysts (plagioclase, Kfeldspar, biotite) derived from the host rocks within the enclaves or even crosscutting the contacts between enclaves and hosts, calls strongly for mass transfer between interacting magmas.

Even though the presence of enclaves and disequilibrium textures testifies for magma mixing in the basic group, these features are lacking in the two-mica granite and the leucogranite. There is no macroscopic or petrographic evidence that would indicate widespread opensystem petrogenetic processes, regardless isotopic variation observed in both groups.

All SPC rocks display variable present-day $\mathrm{Sr}$ isotopic compositions that cannot be explained solely by variable abundances of initial ${ }^{87} \mathrm{Rb}$. The isotopic data do not define any reasonable isochron(s), but are rather scattered indicating that magmatic masses have been affected by open-system processes. These considerations are valid for the whole SPC except the two-mica granite rocks. The latter plot on an isochron with good Mean Square of Weighted Deviates (MSWD $=1.2$ ), indicating that their internal variability can be explained by closedsystem crystallization (Christofides et al., 1990).

\subsection{Numerical testing of the petrogenetic hypotheses}

\subsubsection{Derivation of SPC rocks from a single parental basic magma}

Different hypotheses can be proposed in the attempt of explaining magmatic evolution of SPC rocks by derivation from a single parental basic magma.

As shown by isotopic variability and the presence of enclaves in the basic group, close-system crystal fractionation by itself is not able to explain the evolution of all the Sithonia rocks.
Likewise, assimilation of crustal materials by a single parental magma coupled with fractional crystallization (De Paolo, 1981) fails to explain the presence of variously hybrid mafic microgranular enclaves, which indicates the existence of different batches of magmas rather than crustal assimilation alone. In addition, calculations of $r$ and $F$ parameters of an Assimilation plus Fractional Crystallization (AFC) process (De Paolo, 1981), using as a proxy for the basic parental magma the least evolved enclaves and as contaminant the composition of either gneisses or amphibolites of Serbo Macedonian Massif (samples AA1 and 141A, Tables 24), show that extremely high degree of fractionation (up to $80 \%$ ) is needed to generate the acid rocks. This process would have produced large volumes of cumulates for which there is no evidence in the area. In addition, it must be stressed that the majority of the rocks of the basic group are intermediate in composition and the true basic magmas of SPC form only a few percent of the whole plutonic complex.

Taken together, any evolution starting from a single parental mafic magma fails to explain the evolution of all the SPC rocks.

\subsubsection{Derivation of SPC rocks by interaction among different magmas}

Trace element abundances (Fig. 5) show that geochemistry of tonalite, hornblende-biotite granodiorite and biotite granodiorite is intermediate between the acid group and the enclaves, indicating a possible genetic link between the basic group and the acid group rocks.

A bulk binary mixing between mafic and felsic magmas is not a viable process to explain the genesis of all rocks. It should produce rectilinear trends on binary plots which is not true for the Sithonia rocks (Figs. 4 and 5).

An alternative hypothesis could be magma mixing coupled with fractional crystallization generating intermediate rocks. Such a process, assuming presence of a felsic magma chamber invaded by a mafic magma, could in principle explain the observed major-and trace element, as well as isotopic variability. In addition it would account for the occurrence of enclaves and disequilibrium textures in minerals, but only in the intermediate rocks.

From a geochemical point of view, the most appropriate model would be Mixing plus Fractional Crystallization (MFC) (e.g. Poli et al., 1996; Poli and Tommasini, 1999), with a mathematical formulation analogous to the AFC (De Paolo, 1981). According to this model, the assimilant would be a felsic magma, into which a mafic magma intrudes and mixes. Further details about this model and its applicability to magma 
evolution in plutonic rocks can be found in Poli et al. (1996). The use of the MFC model requires the choice of two end-member magmas. In the SPC, a reasonable approximation for the acid end-member could be the average composition of the acid group rocks, because they existed as magma at approximately the same time as the basic group did. However, the two-mica granite is slightly older than the leucogranite and the latter is coeval with the basic group on the basis of both geochronological and field data. Therefore, for the MFC process the average composition of the leucogranite appears more reasonable. Regarding the mafic end-member, outcrops of mafic rocks are lacking in the studied area. However, the least evolved (monzonitic) enclaves still retain a rather primitive geochemical character, although they may have been affected by some interaction with the host magma. Therefore, we assume that the mafic endmember can be represented by the least evolved enclaves. In particular, we consider an average composition of monzonitic enclaves with $\mathrm{V}$ contents higher than ca. $130 \mathrm{ppm}$ as a proxy for the original mafic magma. Note that a different threshold value for $\mathrm{V}$ does not affect significantly presented results.

\subsection{MFC modelling}

Results of the MFC modelling are presented in Fig. 9A, showing the variation of ${ }^{87} \mathrm{Sr} /{ }^{86} \mathrm{Sr}$ initial ratio vs. V. Vanadium is chosen as the differentiation index because this element discriminates well the degree of geochemical evolution of Sithonia rocks. In the model, two lines of descent are calculated by varying the values of $r, D_{\mathrm{Sr}}$ and $D_{\mathrm{V}}$ in the De Paolo (1981) equations until a best fit is achieved encompassing the observed variability. The two lines of descent bound a set of models with $r, D_{\mathrm{Sr}}$ and $D_{\mathrm{V}}$ intermediate values. Used values of chosen $r, D_{\mathrm{Sr}}$ and $D_{\mathrm{V}}$ are given in the graph. Results show that the MFC modelling could be considered satisfactory for explaining the evolution of all the basic group rocks. Note that using $\mathrm{Nd}$ isotopic ratios yields the same results.

If the MFC model obtained by using isotopic abundances is correct, the same $r, D_{\mathrm{Sr}}$ and $D_{\mathrm{V}}$ values used in Fig. 9A must also explain sample variability in the $\mathrm{V}$ vs. $\mathrm{Sr} / \mathrm{V}$ graph of Fig. 9B. Accordingly, the lines of descent were calculated using the same model parameters as for isotopes. It is clear from the graph that the calculated evolution lines fail to model the sample variability. Fig. 9C shows that in order to encompass trace element variability, different values of $r, D_{\mathrm{Sr}}$ and $D_{\mathrm{V}}$ have to be used.

The above results indicate that there is a clear dichotomy in the geochemical behaviour of isotopes

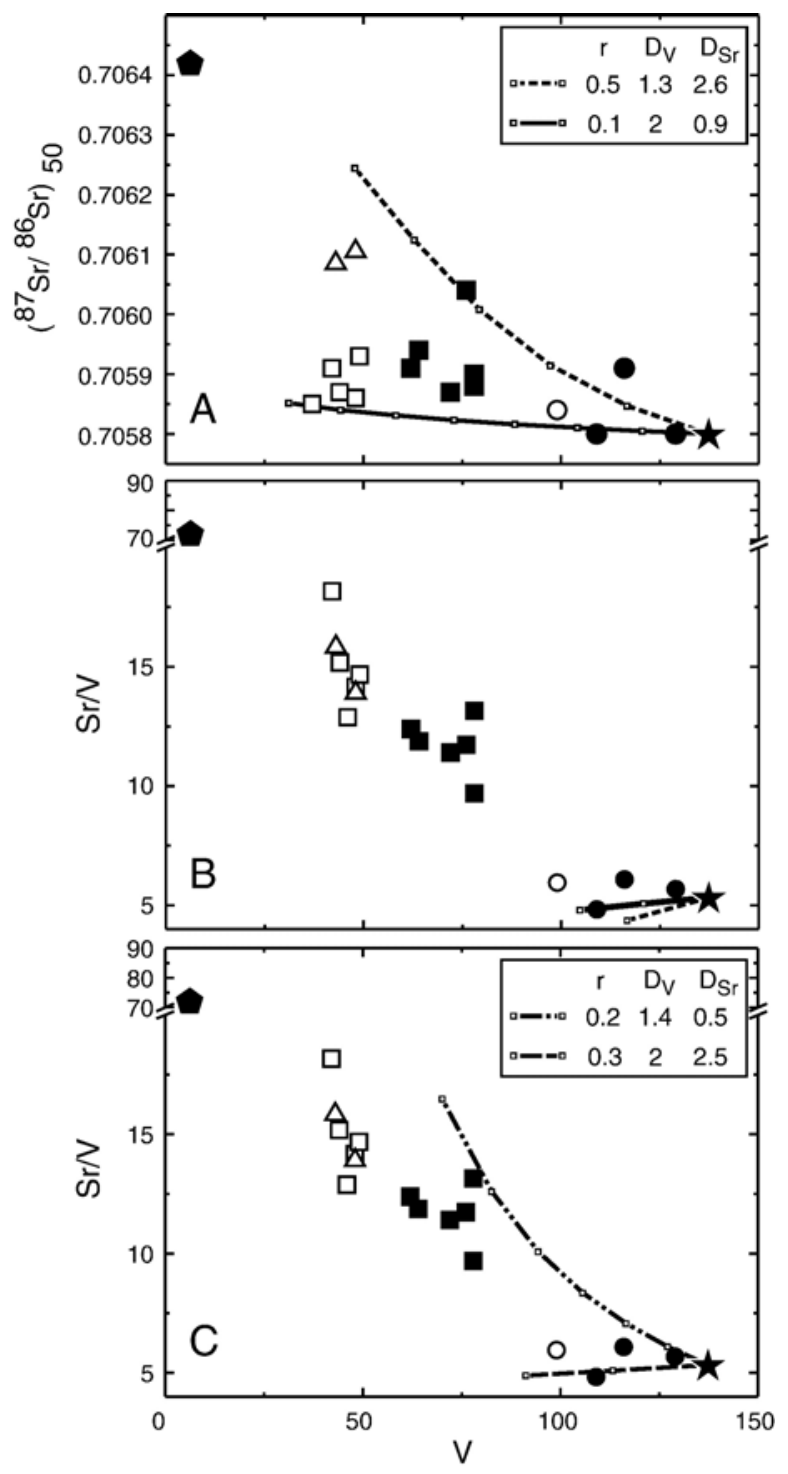

Fig. 9. (A) $\left({ }^{87} \mathrm{Sr} /{ }^{86} \mathrm{Sr}\right)_{50}$ vs. V diagram showing the two MFC lines needed to encompass the variability of composition of the basic group rocks. (B) Sr/V vs. V diagram. The two MFC lines, calculated with the parameters used in A fail to reproduce the variability in the basic group. (C) Sr/V vs. V diagram showing the improvement of the fitting by using different values of $r$ and $D$. Solid star, mafic end-member (average composition of monzonitic enclaves with $\mathrm{V}$ contents higher than ca. $130 \mathrm{ppm}$ ); solid pentagon, acid end-member (average composition of leucogranite); tick marks are reported at $10 \%$ intervals of crystal fractionation; $r$, rate of mixing over rate of fractional crystallization; $D$, bulk partition coefficient. Other symbols as in Fig. 3.

and trace elements in the studied rocks. A possible explanation may be the sharp difference in the diffusion rates: the isotope diffusion is more than one order of magnitude faster than the trace element diffusion (Baker, 1989; Lesher, 1990; Van der Laan et al., 1994). 
Accordingly, compositional differences, such as those generated during interaction between magmas with different compositions, would decouple the isotopes from the trace elements (e.g. Pin et al., 1990; Poli et al., 1996). Thus the isotopes would reflect combined effects of both chemical diffusion and differentiation. On the other hand, the trace elements are mostly controlled by evolutionary processes, being affected by diffusion to a lesser extent. Thus, in magmatic systems whose evolution is linked to the interaction between different magmas, the trace elements are more appropriate to track magma evolution, than the isotopes (e.g. Pin et al., 1990; Poli et al., 1996). Therefore, the geochemical modelling performed using trace elements (Fig. 9C) is the preferred method to unravel the geochemical evolution of the SPC.

Worth stressing is that parameters of the MFC are likely to have changed with time. Clearly, during magma interaction strong thermal and rheological contrasts may exist between the mafic and felsic magma (e.g. Sparks and Marshall, 1986; Poli et al., 1996). These are the most pronounced at the initial stages of the interaction, when the under-cooling of the mafic magma, in contact with the colder felsic one, induces the mafic magma crystallization. At this stage, the fragmentation and dispersion of the mafic magma into the felsic one is inhibited. Hence the rate of mixing is low compared to the rate of crystallization of the mafic magma (i.e. parameter $r$ is low). However, with proceeding interaction, the thermal and rheological contrasts between magmas are progressively smoothed out (Sparks and Marshall, 1986; Poli et al., 1996). As a result the fragmentation and dispersion of the mafic into the felsic magma becomes more important, leading to a predominance of the mixing process (i.e. increasing values of parameter $r$ ).

These considerations indicate that a single set of parameters for the MFC process is not feasible, because the importance of mixing should increase with time relative to the rate of fractional crystallization. In addition, a single MFC process, although theoretically possible, would require degrees of fractional crystallization of the mafic magma up to $70 \%$. As discussed previously such high degrees of fractionation are not consistent with the observed proportions of acid and basic rocks in the SPC.

Accordingly a two-step MFC model is proposed, with different values of $r$ for each step. The first step (MFC-1) is intended to explain the geochemical variation of monzonitic enclaves and the genesis of tonalitic enclaves. Once an evolved mafic magma is generated (that parental to the tonalitic enclaves) a second MFC step (MFC-2) is invoked. It should represent the successive stages of the evolution dominated by mixing and thus to explain the geochemical variation of tonalite, hornblende-biotite granodiorite, and biotite granodiorite. The initial mafic and felsic magmas envisaged above are used as end-members for the first step. For the second step, the felsic magma does not change and the mafic magma is assumed to be an average of the more evolved tonalitic enclaves.

The diagrams (Fig. 10) show that the calculated lines of descent for trace elements reproduce the trace element data quite well. The value of $r$ used in the MFC-1 model is ca. 0.1 indicating that mixing played a minor role with respect to fractional crystallization. Regarding MFC-2, the $r$ value has been increased to 0.4 , and some $D$ values for the same trace elements have been changed (Fig. 10). The increase of $r$ reflects a major role played by mixing, and changing of $D$ indicates a variation in the proportions of the fractionating mineralogical assemblage passing from MFC-1 to MFC-2. In this context worth noting is that the variability of fractionating assemblages is in agreement with petrographic features of the modelled rocks. In particular, from MFC-1 to MFC-2 the decrease of $D_{\mathrm{Rb}}$ and $D_{\mathrm{Ba}}$ and the increase of $D_{\mathrm{Sr}}$ and $D_{\mathrm{Zr}}$ suggest a lesser proportion of biotite and higher role for feldspars and zircon, respectively. It is also noticeable that $D_{\mathrm{V}}$ increases from MFC-1 to MFC-2. Although this could appear in contrast with common evolutionary processes that would result in a decrease of $D$ for ferromagnesian elements during evolution, it must be stressed that mafic melts of SPC share many common geochemical features with lamprophyric melts found in the study area (see below). In lamprophyric magmas, major mafic minerals are represented by clinopyroxene and phlogopite both having lower $K_{\mathrm{D}}$ for $\mathrm{V}$ than amphibole in amphibole-bearing rocks. Amphibole is not common in the monzonitic enclaves and is infrequent relative to biotite in the tonalitic enclaves (Perugini et al., 2003). On the contrary, amphibole is a major mafic mineral phase in all other rock types of the basic group except in the biotite granodiorite. This implies that $D_{\mathrm{V}}$ for MFC-1 has to be lower than $D_{\mathrm{V}}$ for MFC-2, in agreement with the presented geochemical modelling.

For some elements, such as $\mathrm{Nb}, \mathrm{Y}, \mathrm{Zr}$ and $\mathrm{REE}$, data points display some scatter (Fig. 10D and E), and in some cases MFC-2 is unable to model the sample variability (Fig. 10F). These elements are hosted mainly in accessory minerals which are typically distributed very inhomogeneously in the SPC samples, particularly epidote. This implies that even small variation of the absolute abundances of these minerals can cause large variability of concentration of the above mentioned elements. Therefore, we suggest that the scatter in the graphs and the inability of MFC-2 to model some elements is mainly due 

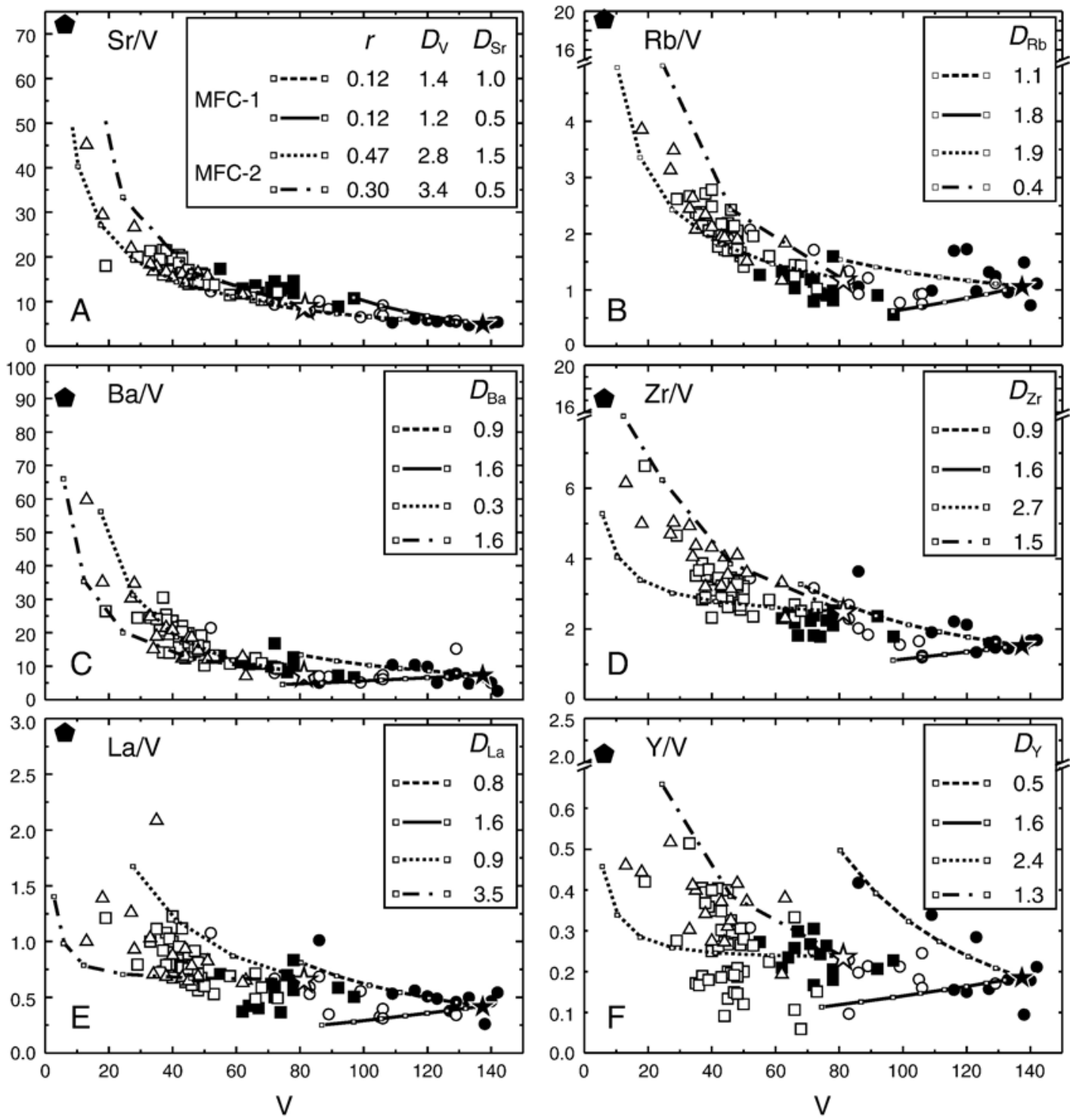

Fig. 10. Binary diagrams showing the two MFC steps, MFC-1 and MFC-2, thought to be responsible for the evolution of the enclaves and the other basic group rocks, respectively. Each step requires two lines to account for the variability of both the enclaves and the other basic rocks. Solid star, mafic end-member for step MFC-1 (average composition of monzonitic enclaves with V contents higher than ca. 130 ppm); open star, mafic endmember for step MFC-2 (average of the more evolved tonalitic enclaves); solid pentagon, acid end-member for both steps (average composition of leucogranite); tick marks are reported at $10 \%$ intervals of crystal fractionation; $r$, rate of mixing over rate of fractional crystallization; $D$, bulk partition coefficient. Other symbols as in Fig. 3.

to the inhomogeneous distribution of these minerals in studied samples.

\subsection{Origin of mafic and felsic magmas}

Two parental magmas, one basic and one acid, were involved in the genesis of the SPC. The Sithonia area lies in a very complex geodynamic setting that, since Jurassic, underwent at least two consecutive subduction events due to the closure of two adjacent oceans (e.g. Perugini et al., 2004). Based on this evidence, it has been suggested that the mantle wedge underlying the study area suffered variable degrees of metasomatism induced by fluids released from the subducting and dehydrating oceanic lithosphere (Perugini et al., 2004). Such metasomatic processes generated a strongly inhomogeneous mantle wedge ('leopard-skin' mantle wedge; Perugini et al., 2004), variably enriched in incompatible 
elements. Its melting would have generated mafic melts with variable enrichment in incompatible elements, having a large range of geochemical signatures from calc-alkaline to lamprophyric (e.g. Perugini et al., 2004). The spider diagram (Fig. 11) for the monzonitic enclaves shows their lamprophyric affinity, and indicates that a mantle-derived lamprophyric-like magma can be considered a suitable original mafic magma, from which the enclaves were derived.

Regarding the felsic end-member, the composition of the leucogranite displays strong isotopic and trace element variability that cannot be explained by closedsystem processes. On the other hand, macroscopic (enclaves) and textural (e.g. disequilibrium in mineral phases) evidence of strong magma interaction processes are lacking. In addition, the variability of major-element chemistry of the leucogranite is much narrower than the spread in isotopic and the trace element compositions. Therefore, an open-system process affecting isotopes and trace elements and keeping major elements almost constant is required. Snyder and Tait (1998) showed that this can be the case when a felsic magmatic mass overlies a mafic magmatic body. At the beginning, the two magmatic masses tend to remain separated because of the density contrast, but this does not preclude chemical exchanges. Thermal differences between magmas lead to convection in each of the two magmas, and this promotes chemical diffusion at the boundary layer and dispersion of chemical elements in both magmas (Snyder and Tait, 1998). This convection-diffusion process mostly influences the elements that have the highest diffusivity. As discussed above, among chemical species, isotopes (such as $\mathrm{Sr}$ and $\mathrm{Nd}$ ) have the highest diffusion coefficients (e.g. Lesher, 1990) followed by trace elements (Snyder and Tait, 1998), whereas all major

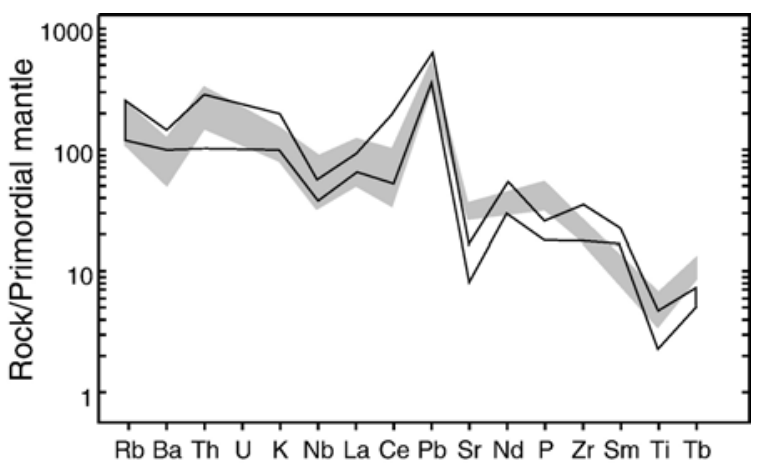

Fig. 11. Primordial mantle normalized (Wood et al., 1979, 1981 (Ti); McDonough et al., $1992(\mathrm{~Pb})$ ) spider diagram for monzonitic enclaves (shaded region) with $\mathrm{V}$ content higher than $130 \mathrm{ppm}$. The area delimited by black lines represents lamprophyric dykes found in boreholes in eastern Chalkidiki (Kalogeropoulos et al., 1991).

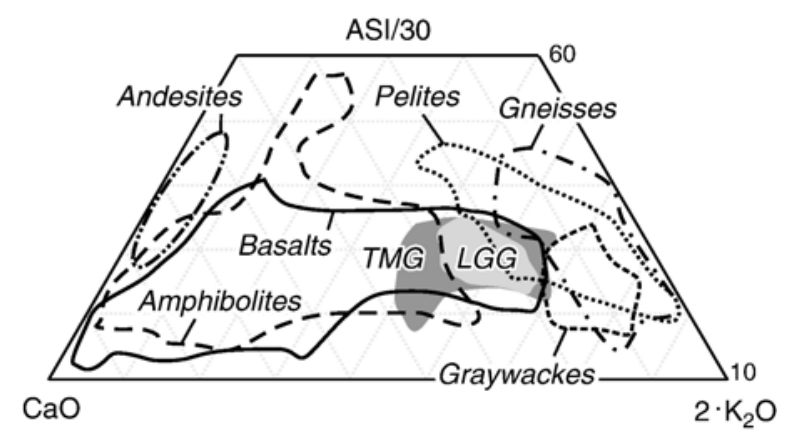

Fig. 12. The $\mathrm{CaO}-\mathrm{Al}_{2} \mathrm{O}_{3} /\left(\mathrm{Na}_{2} \mathrm{O}+\mathrm{K}_{2} \mathrm{O}+\mathrm{CaO}\right)(\mathrm{ASI})-2 \cdot \mathrm{K}_{2} \mathrm{O}$ (molar) diagram displaying the composition of the two-mica granite (TMG) and leucogranite (LGG) compared with experimental data of melt compositions from different crustal protoliths at pressure higher than 5.0 Kbar. Data are as follows: greywackes and pelites (MacRae and Nesbitt, 1980; Skjerlie et al., 1993; Carrington and Watt, 1995; Gardien et al., 1995; Patino Douce and Beard, 1996; Montel and Vielzeuf, 1997; Pickering and Johnston, 1998); gneisses (Holtz and Johannes, 1991; Skjerlie et al., 1993; Beard et al., 1994; Gardien et al., 1995; Patino Douce, 1997); amphibolites (Beard and Lofgren, 1991; Rushmer, 1991; Wolf and Wyllie, 1994; Johannes and Holtz, 1996); basalts (Rapp, 1995; Rapp and Watson, 1995). In average the degree of melting varies from minimum melts to ca. $20 \%$.

elements have the lowest ones. This happens because the diffusion of major elements is controlled mostly by $\mathrm{Si}$ and $\mathrm{Al}$, which are network-forming cations, and therefore diffusion requires restructuring of the melt, which is difficult to achieve. On the other hand, diffusion of isotopes and trace elements does not require melt restructuring and, therefore, mobility of these species in the melt is much higher. As the coexistence of coeval mafic and felsic melts is documented in the Sithonia area, the above process could be invoked to explain the geochemical features of the leucogranite.

Given that trace element and isotopic signatures of the leucogranite are likely to have been affected by magma interaction processes, they cannot be used to constrain leucogranite source. On the contrary, major elements offer much better insights on this. The high degree of evolution of the leucogranites $\left(\mathrm{SiO}_{2} \mathrm{ca} .73 \%\right)$ coupled with the fact that they cannot be derived by crystal fractionation from a basic parental magma, as explained above, suggests a genesis by partial melting of crustal material. To constrain the possible source of leucogranites they are plotted in the ternary graph of Fig. 12 together with experimental data obtained by melting experiments of crustal protoliths. Geobarometric data indicate an emplacement pressure for the Sithonia rocks of about 5.0 Kbar, which implies that melt production occurred even deeper. For this reason in Fig. 12 only experimental melts generated under pressure greater than $5.0 \mathrm{Kbar}$ are plotted. The graph shows that greywackes and orthogneisses are not suitable source 
rocks for the leucogranite magma, whereas pelites, basalts, and amphibolites partially overlap with the leucogranite. However, Sr isotopic values of the leucogranite are quite low and inconsistent with mature metasedimentary sources and, thus, they are not likely to be suitable sources for the leucogranite magma. Therefore, middle-lower crustal rocks (intermediate-basaltic compositions, i.e. amphibolites and basalts) may be appropriate candidates indicating a possible source for the leucogranite magma. This hypothesis is corroborated by different observations: i) despite the occurrence of muscovite in the leucogranite, alumina-saturation index values for these rocks $(<1.2)$ are below those of typical peraluminous magmas derived by partial melting of most upper crustal sources (e.g. Tate and Clarke, 1997; Sylvester, 1998); moreover, the leucogranites are not typical products of crystallization of true peraluminous magmas because Al-rich phases such as cordierite, garnet, or alumina-silicates are lacking (Sylvester, 1998); ii) the relatively primitive isotopic signature of the leucogranite indicates melting of a young intermediate basaltic crust.

As reported above, the acid group contains also twomica granite, which displays constant isotopic composition and little variability of major-and trace element abundances. In addition, two-mica granite samples define an isochron indicating a limited internal evolution that can be due to closed-system processes such as fractional crystallization. As for the leucogranite, the high evolved nature of the two-mica granite suggests a genesis by partial melting of crustal material. In Fig. 12 the two-mica granite and leucogranite fields overlap, indicating that a common source can be invoked for their genesis.

The presumed common source and the strong similarity of the leucogranite and two-mica granite suggest a genetic link between the two rock types. In particular, it can be speculated that they originally were a single batch of magma which underwent different petrogenetic histories. The two-mica granite may represent the original partial melt that migrated from the source region and was emplaced at about $50 \mathrm{Ma}$, whereas the leucogranite may be interpreted as the result of contamination of the two-mica granite magma by convection-diffusion processes caused by its underplating by the lamprophyric mafic magma.

The aplites and pegmatites show REE patterns, a strong Eu anomaly, a very high $\mathrm{Rb} / \mathrm{Sr}$ ratio, and high $\mathrm{Nb}$ abundances indicating that they were generated by extreme degrees of fractionation (e.g. Poli, 1992).

\section{Summary and conclusions}

The study of the Sithonia Plutonic Complex suggests that a mafic, mantle-derived magma with lamprophyric affinity underplated a lower crust of amphiboliticbasaltic composition, whose partial melting generated a magma with an average composition analogous to that of the two-mica granite (Fig. 13A). The bottom part of the two-mica granite magma, at the contact with the mafic magma, was contaminated by convection-diffusion processes generating a magma with leucogranite geochemical signature.

At ca. $50 \mathrm{Ma}$, the two-mica granite magma migrated towards higher crustal levels and was emplaced at a depth of ca. $15 \mathrm{~km}$, where it solidified as the two mica granite that forms the northern part of the Sithonia Plutonic Complex.

Fig. 13B and C illustrate the two-step MFC model, occurring in the lower crust, suggested to explain the genesis of the basic group. During the first MFC step (MFC-1; Fig. 13B), the mafic magma underwent fast cooling, preventing efficient mixing processes. This was because of the strong thermal and rheological contrast between the mafic and felsic magmas (see above). At this stage, crystallization of the mafic magma dominated over its fragmentation and dispersion into the felsic one. The result was the formation of the less evolved monzonitic enclaves, which are the largest and geochemically the least evolved. The mafic magma evolved to give a batch with the geochemical composition of the tonalitic enclaves. As the rheological barriers between the evolved mafic magma (tonalitic enclaves) and the felsic magma were reduced, the degree of fragmentation and dispersion of the mafic magmas increased, as did the role of the mixing relative to the fractional crystallization (MFC-2; Fig. 13C). The increasing efficiency of the mixing generated the compositional spectrum of the tonalite, hornblende-biotite granodiorite and biotite granodiorite magmas, all bearing mafic microgranular enclaves and mineral disequilibrium textures.

The fluid-dynamics instability generated by the mixing process induced migration of magmas towards higher crustal levels at a depth of ca. $15 \mathrm{~km}$. On the basis of field evidence, the first mass emplaced at ca. $46 \mathrm{Ma}$ was the hornblende-biotite granodiorite containing blobs of tonalite, followed by the leucogranite. Last mass to be emplaced within the main magmatic phase of the Sithonia Plutonic Complex was the biotite granodiorite. The very last magmatic event generated minor aplites and pegmatites, possibly associated with volume shrinkage of solidifying plutonic masses at the emplacement level.

The rocks of the Sithonia Plutonic Complex show characteristics of pre-plate collisional setting indicating subduction-related magma genesis. This is well documented by the fact that magmas envisaged as mafic end- 

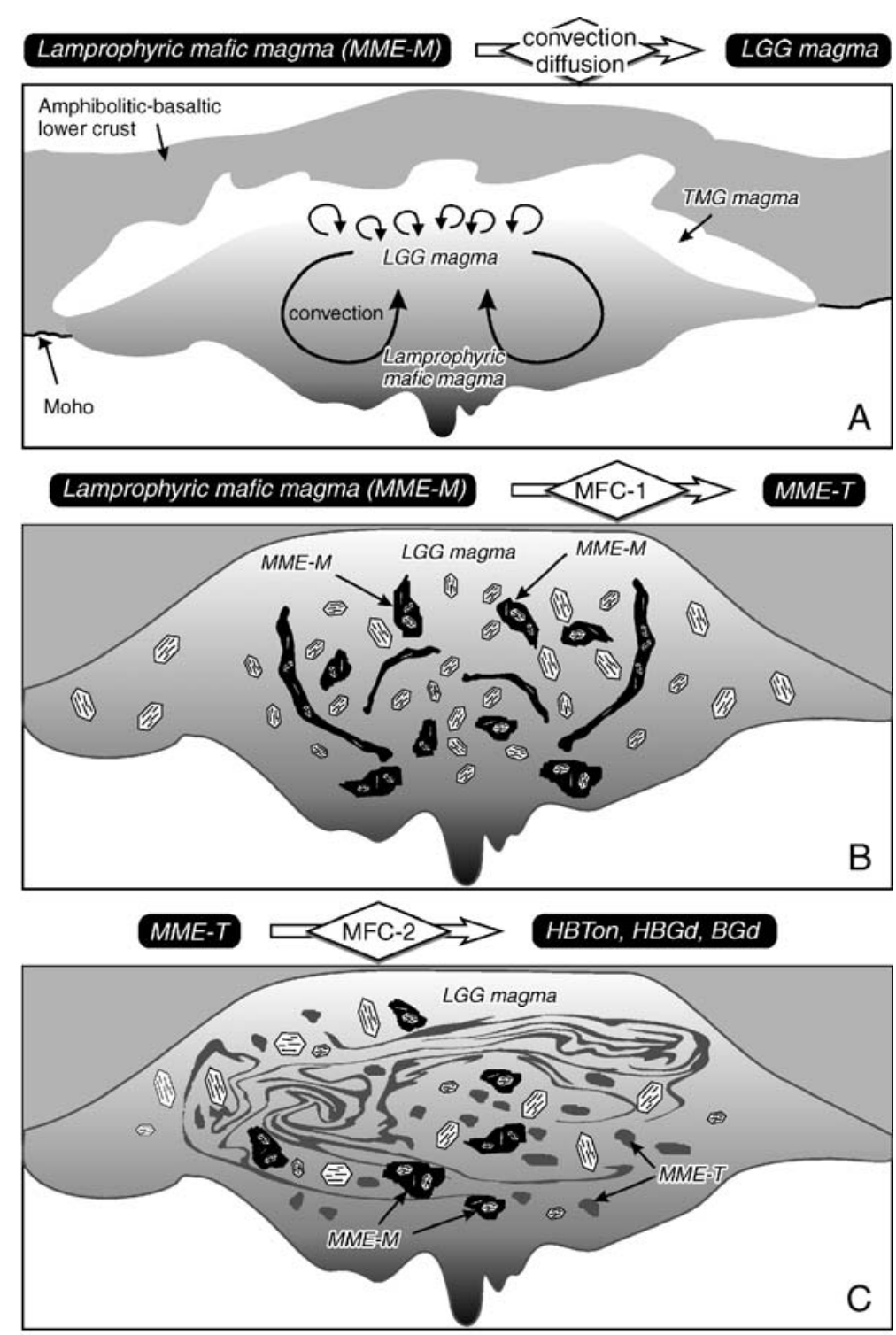

Fig. 13. Schematic model for genesis of magmas of the Sithonia Plutonic Complex. (A) Genesis of the two-mica granite (TMG) magma by anatexis of the middle to lower crust due to underplating by lamprophyric mantle-derived magmas (MME-M, monzonitic enclaves). Shown is also origin of the leucogranite (LGG) magma by a convection-diffusion process. (B) First stage of the MFC process (MFC-1) leading to the formation of the tonalitic enclaves (MME-T). (C) Second stage of the MFC process (MFC-2) yielding the tonalite (HBTon), hornblende-biotite granodiorite (HBGd) and biotite granodiorite (BGd) magmas. Not to scale. See text for detailed explanation of the various stages.

member for the petrologic evolution of SPC display typical features of melts generated by melting of a mantle wedge metasomatized by fluids enriched in incompatible elements released by subducting oceanic slabs (i.e. Fig. 11). The general petrologic and geochemical features of SPC have been also recognized in other intrusive magma bodies in the study area, such as in the Rhodope massif (Christofides et al., 1998) and central Cyclades (Altherr and Siebel, 2002). Until recently, SPC and other Eocene plutons in the Serbo-Macedonian and
Hellenic Rhodope Massifs were considered as related to Vardar (Axios) ocean or even to Pindos ocean subduction (Robertson and Dixon, 1984; De Wet, 1989). However, the Eocene age and the geotectonic setting of SPC do not concur with such a subduction event since closure of the Pindos and Vardar (Axios) oceans was complete by late Cretaceous-early Eocene. On the other hand, according to Pe-Piper (2004) magma genesis of Eocene plutons in Northern Greece was probably related to the subduction of the Intra-Pontide Ocean which Görür and 
Okay (1996) suggested as closing in the Oligocene. An Eocene subduction is also supported by $\mathrm{U}-\mathrm{Pb}$ ion microprobe (SHRIMP) dating on zircons $(45.3 \pm 0.9 \mathrm{Ma}$ for early stages of subduction), combined with well determined $P-T-t$ (relative) paths for the metamorphic rocks of the Sidironero Unit of HRM (Liati et al., 2002).

\section{Acknowledgements}

We thank two anonymous reviewers for their constructive comments. We also thank G. Pe-Piper and D. Piper for the language correction and useful suggestions. This work was founded the by Italian MIUR and University of Perugia grants.

\section{Appendix A. Analytical techniques}

Major elements of the minerals were determined by electron microprobe analysis using the Modified Cambridge Geoscan with Link Systems EDS at Manchester University, and a Jeol 740 SEM at the Thessaloniki University.

Micas and amphibole were separated by a combination of magnetic separator and heavy liquids. The purity estimated by microscopic examination is $\sim 99.8 \%$; contaminant is mainly zircon. Trace element analysis of the separates was carried out by $\mathrm{X}$-ray fluorescence. $\mathrm{Li}$ as well as total $\mathrm{Fe}_{2} \mathrm{O}_{3}$ in micas were determined by atomic absorption, whereas $F$ concentrations were obtained by selective ion electrode analysis with a precision of about $2 \%$. Finally, $\mathrm{FeO}$ of rocks and mineral fractions was determined by titration with a standardized potassium permanganate solution, with a precision of about $1 \%$ (Manchester University).

Rock major-and trace element analyses were carried out by a combination of X-ray fluorescence and atomic absorption spectrometry, at the Universities of Bologna, Pisa, Perugia and Manchester. Thorough inter-laboratory checking showed good agreement. The LOI was determined by heating at $1050{ }^{\circ} \mathrm{C}$. The precision is better than $10 \%$ for $\mathrm{V}, \mathrm{Cr}, \mathrm{Ni}, \mathrm{Y} \mathrm{Zr}$ and $\mathrm{Ba}$ and better than $5 \%$ for all other elements. REE analyses were performed by inductively coupled plasma-atomic emission spectroscopy (ICPAES) at the Mineralogisch-Geochemisches Institut, Universität Köln. Precision is better than $10 \%$ for all REE.

$\mathrm{Rb}$ and $\mathrm{Sr}$ concentration were determined by isotope dilution using mixed spike of ${ }^{87} \mathrm{Rb}$ and ${ }^{84} \mathrm{Sr}$. Analytical error of ${ }^{87} \mathrm{Rb} /{ }^{86} \mathrm{Sr}$ ratio is $1 \%$ (95\% confidence limit). Sm and Nd concentrations were determined by ICP-AES, with precision better than $5 \%$. Isotopic analyses were made by VG-Isomass 54E thermal ionization mass spectrometer. Replicate analyses of NBS RSM 987 and La Jolla standards allowed to estimate an external reproducibility better than $1 \times 10^{-5} \cdot{ }^{87} \mathrm{Sr} /{ }^{86} \mathrm{Sr}$ ratios were normalized to ${ }^{86} \mathrm{Sr} /{ }^{88} \mathrm{Sr}=0.1194$ and then adjusted to ${ }^{87} \mathrm{Sr} /{ }^{86} \mathrm{Sr}=0.71025$ for NBS RSM 987 standard. ${ }^{143} \mathrm{Nd} /{ }^{144} \mathrm{Nd}$ ratios were normalized to ${ }^{146} \mathrm{Nd} /{ }^{144} \mathrm{Nd}=0.7219$ and then adjusted to ${ }^{143} \mathrm{Nd} /{ }^{144} \mathrm{Nd}=0.51185$ for La Jolla standard. Quoted errors are given at $2 \sigma$ and refer to the last digit. Initial ratios were calculated at $50 \mathrm{Ma}$. Isotopic measurements were made at CNR laboratories in Pisa (Italy).

\section{References}

Altherr, R., Siebel, W., 2002. I-type plutonism in a continental backarc setting: Miocene granitoids and monzonites from the central Aegean Sea, Greece. Contributions to Mineralogy and Petrology 143, 397-415.

Baker, D.R., 1989. Tracer versus trace element diffusion: diffusional decoupling of $\mathrm{Sr}$ concentration from $\mathrm{Sr}$ isotope composition. Geochimica et Cosmochimica Acta 53, 3015-3023.

Beard, J.S., Lofgren, G.E., 1991. Dehydration melting and watersaturated melting of basaltic and andesitic greenstones and amphibolites at 1, 3 and $6.9 \mathrm{~Kb}$. Journal of Petrology 32, 365-401.

Beard, J.S., Lofgren, G.E., Sinha, A.K., Tollo, R.P., 1994. Partial melting of apatite bearing charnockite, granulite, and diorite: melt composition, restite mineralogy and petrologic implications. Journal of Geophysical Research 99 (B11), 21591-21603.

Bebien, J., Baroz, F., Capedri, S., Venturelli, G., 1987. Magmatismes basiques associés à l' ouverture d'un basin marginal dans les Hellenides internes au Jurassique. Ofioliti 12, 53-70.

Bebien, J., Michard, A., Montigny, R., Feinberg, H., Voidomatis, P., 2001. The Grigoriou plutonic complex (Mt. Athos, Greece): a component of the north Aegean Eocene-Oligocene calc-alkaline magmatism. Journal of Conference Abstracts Vol. 611 th EUG, p. 314.

Carrington, D.P., Watt, G.R., 1995. A geochemical and experimental study of the role of K-feldspar during water-undersaturated melting of metapelites. Chemical Geology 122, 59-76.

Castro, A., Moreno-Ventas, I., De La Rosa, J.D., 1991. Multistage crystallization of tonalitic enclaves in granitoids rocks (Hercinian Belt, Spain): implications for magma mixing. Geologische Rundschau 80, 109-120.

Christofides, G., Eleftheriadis, G., 1992. Magmatic epidote from the Sithonia plutonite. (in Greek with English abstract). Annales Géologiques des Pays Helléniques 35, 389-400.

Christofides, G., D'amico, C., Del Moro, A., Eleftheriadis, G., Kyriakopoulos, C., 1990. Rb/Sr geochronology and geochemical characters of the Sithonia plutonic complex (Greece). European Journal of Mineralogy 2, 79-87.

Christofides, G., Eleftheriadis, G., Neiva, M.A., Vlahou, M., Papadopoulou, L., 1998. Major and trace element geochemistry of micas and amphiboles of the Sithonia pluton (Chalkidiki, N. Greece): constraints on its evolution. Bulletin of the Geological Society of Greece XXXII/3, 231-240.

Christofides, G., Koroneos, A., Soldatos, T., Eleftheriadis, G., 2000. Mesozoic magmatism in the area between the Vardar (Axios) zone and the Serbomacedonian massif (northern Greece). In: Karamata, S., Jankovic, S. (Eds.), Geology and Metallogeny of the Dinarides and the Vardar ZoneBulletin de Académie Serbe des Sciences et des Arts, Classe des sciences mathématiques et naturellesSciences naturelles, pp. 111-120. 
Christofides, G., Koroneos, A., Soldatos, T., Eleftheriadis, G., Kilias, A., 2001. Eocene magmatism (Sithonia and Elatia plutons) in the Internal Hellenides and implications for Eocene-Miocene geological evolution of the Rhodope massif (Northern Greece). In: Downes, H., Orlando, V. (Eds.), Tertiary Magmatism in the DinaridesActa Vulcanologica, vol. 13, pp. 73-89.

D’Amico, C., Christofides, G., Eleftheriades, G., Bargossi, G.M., Campana, R., Soldatos, T., 1990. The Sithonia Plutonic Complex (Chalkidiki, Greece). Mineralogica et Petrographica Acta 33, 143-177.

De La Roche, H., Leterrier, J., Grande Claude, P., Marchal, M., 1980. A classification of volcanic and plutonic rocks using $R_{1}-R_{2}$ diagrams and major element analyses-its relationships with current nomenclature. Chemical Geology 29, 183-210.

De Paolo, D.J., 1981. Trace elements and isotopic effects of combined wallrock assimilation and fractional crystallisation. Earth and Planetary Science Letters 53, 189-202.

De Wet, A.P., 1989. Geology of part of the Chalkidiki Peninsula, Northern Greece. ( $\mathrm{PhD}$ Thesis), Wolfson College, Cambridge, $177 \mathrm{pp}$.

De Wet, A.P., Miller, J.A., Bickle, M.J., Chapman, H.J., 1989. Geology and geochronology of the Arnea, Sithonia and Ouranopolis intrusions, Chalkidiki Peninsula, northern Greece. Tectonophysics $161,65-79$.

Didier, J., Barbarin, B., 1991. Enclaves and granite petrology. Elsevier Developments in Petrology, vol. 13. Amsterdam. 625 pp.

Dimitriadis, S., Asvesta, A., 1993. Sedimentation and magmatism related to the Triassic rifting and later events in the Vardar-Axios zone. Bulletin of the Geological Society of Greece XXVIII/2, 149-168.

Frei, R., 1992. Isotope ( $\mathrm{Pb}, \mathrm{Rb}-\mathrm{Sr} ; \mathrm{S}, \mathrm{O}, \mathrm{C}, \mathrm{U}-\mathrm{Pb})$ geochemical investigations on Tertiary intrusives and related mineralizations in the Serbomacedonian $\mathrm{Pb}-\mathrm{Zn}, \mathrm{Sb}+\mathrm{Cu}-\mathrm{Mo}$ metallogenic province in Northern Greece. (PhD. Thesis), Swiss Federal Institute of Technology (ETH), $231 \mathrm{pp}$.

Gardien, V., Thompson, A.B., Grujic, D., Ulmer, P., 1995. Experimental melting of biotite + plagioclase + quartz + or - muscovite assemblages and implications for crustal melting. Journal of Geophysical Research, B 100, 15581-15591.

Görür, N., Okay, A.I., 1996. Fore-arc origin of the Thrace Basin, northwest Turkey. Geologische Rundschau 85, 662-668.

Harris, N.B.W., Pearce, J.A., Tindle, A.G., 1986. Geochemical characteristics of collision-zone magmatism. In: Coward, M.P., Ries, A.C. (Eds.), Collision Tectonics Geological Society Special Publications, vol. 19, pp. 67-81.

Haskin, L.A., Frey, F.A., Schmitt, R.A., Smith, R.H., 1966. Meteoritic, solar and terrestrial rare-earth distributions. Physics and Chemistry of the Earth. Pergamon Press, New York, pp. 167-321.

Hildreth, W., Moorbath, S., 1988. Crustal contributions to arc magmatism in the Andes of Central Chile. Contributions to Mineralogy and Petrology 98, 455-489.

Holtz, F., Johannes, W., 1991. Genesis of peraluminous granites. I. Experimental investigation of melt composition at 3 and $5 \mathrm{~Kb}$ and various $\mathrm{H}_{2} \mathrm{O}$-activities. Journal of Petrology 32, 935-958.

Janousek, V., Braithwaite, C.J.R., Bowes, D.R., Gerdes, A., 2004. Magma-mixing in the genesis of Hercynian calc-alkaline granitoids: an integrated petrographic and geochemical study of the Sazava intrusion, Central Bohemian Pluton, Czech Republic. Lithos 78, 67-99.

Johannes, W., Holtz, F., 1996. Petrogenesis and Experimental Petrology of Granitic Rocks. Springer-Verlag, Berlin, Heidelberg, p. 335.

Kalogeropoulos, S.I., Gerouki, F., Papadopoulos, C., 1991. Mineralogy-Geochemistry-genesis and metallogenetic significance of lamprophyres from the Stratoni-Olympias area Kerdilia forma- tion, Eastern Chalkidiki. Bulletin of the Geological Society of Greece XXV/2, 161-173.

Kockel, F., Mollat, H., Walther, H., 1977. Erlauterungen zur geologischen Karte der Chalkidiki und angrezender Gebiete 1:100.000. Bundesanstalt fur Geowissenschaften und Rohstoffe, Hannover, 1-119.

Kostopoulos, D.K., Reischmann, T., Sklavounos, S.A., 2001. Palaeozoic and Early Mesozoic magmatism and metamorphism in the Serbo-Macedonian massif, Central Macedonia, Northern Greece. Journal of Conference Abstracts Vol. 6 11th EUG, p. 318.

Leake, B.E., Wooley, A.R., Birch, W.D., Burke, E.A.J., Ferraris, G., Grice, J.D., Hawthorne, F.C., Risch, H.J., Krivovichev, V.G., Schumacher, J.C., Smith, D.C., Stephenson, N.C.N., Whittaker, E.J.W., 2003. Nomenclature of amphiboles; additions and revisions to the International Mineralogical Association's 1997 recommendations. Canadian Mineralogist 41, 1355-1362.

Lesher, C.E., 1990. Decoupling of chemical and isotopic exchange during magma mixing. Nature 344, 235-237.

Liati, A., Gebauer, D., Wysoczanski, R., 2002. U-Pb SHRIMP-dating of zircon domains from UHP garnet-rich mafic rocks and late pegmatoids in the Rhodope zone (N. Greece); evidence for Early Cretaceous crystallization and Late Cretaceous metamorphism. Chemical Geology 184, 281-299.

MacRae, N.D., Nesbitt, H.W., 1980. Partial melting of common metasedimantary rocks: a mass balance approach. Contributions to Mineralogy and Petrology 75, 21-26.

McDonough, W.F., Sun, S.S., Ringwood, A.E., Jagoutz, E., Hofmann, A.W., 1992. Potassium, rubidium, cesium in the Earth and Moon and the evolution of the Earth's mantle. Geochimica et Cosmochimica Acta 56, 1001-1012.

Michard, A., Feinberg, H., Montigny, R., 1998. Supra-ophiolitic formations from the Thessaloniki nappe (Greece), and associated magmatism: an intra-oceanic subduction predates the Vardar obduction. Compte Rendu Academie des Sciences, Serie II. Sciences de la Terre et des Planetes 327, 493-499.

Miller, C.F., Stoddard, E.F., Bradfish, L.J., Dollase, W.A., 1981. Composition of plutonic muscovite: genetic implications. Canadian Mineralogist 19, 25-34.

Montel, J.M., Vielzeuf, D., 1997. Partial melting of metagreywackes, part II. Compositions of minerals and melts. Contributions to Mineralogy and Petrology 128, 176-196.

Mussallam, K., Jung, D., 1986. Geologie und Bau des SithoniaOphioliths (Chalkidiki, NE-Griechenland): Anmerkungen zur Bildung ozeanischer Krusten. Geologische Rundschau 75, 383-409.

Patino Douce, A.E., 1997. Generation of metaluminous A-Type granites by low pressure melting of calc-alkaline granitoids. Geology 25, 743-746.

Patino Douce, A.E., Beard, J.S., 1996. Effects of $\mathrm{P}, f \mathrm{O}_{2}$ and $\mathrm{Mg} / \mathrm{Fe}$ ratio on dehydration melting of model metagreywackes. Journal of Petrology 37, 999-1024.

Pearce, J.A., Harris, N.B.W., Tindle, A.C., 1984. Trace element discrimination diagrams for the tectonic interpretation of granitic rocks. Journal of Petrology 25, 956-983.

Pe-Piper, G., 2004. Unique features of Greek Cenozoic igneous rocks: tectonics and magma sources. Proceedings of the 5th International Symposium on Eastern Mediterranean Geology, Thessaloniki, Greece, vol. 3, pp. 1208-1211.

Pe-Piper, G., Piper, D.J.W., 2002. The Igneous Rocks of Greece: the Anatomy of an Orogen. Borntraeger, Berlin. 645 pp.

Perugini, D., Poli, G., Christofides, G., Eleftheriadis, G., 2003. Magma mixing in the Sithonia Complex, Greece: evidence from mafic microgranular enclaves. Mineralogy and Petrology 78, 173-200. 
Perugini, D., Poli, G., Christofides, G., Eleftheriadis, G., Koroneos, A., Soldatos, T., 2004. Mantle-derived and crustal melts dichotomy in northern Greece: spatiotemporal and geodynamic implications. Geological Journal 39, 63-80.

Pickering, J., Johnston, A., 1998. Fluid absent melting behaviour of a two mica metapelite: experimental constraints on the origin of Black Hills Granite. Journal of Petrology 39, 1787-1804.

Pin, C., Binon, M., Belin, J.M., Barbarin, B., Clemens, J.D., 1990. Origin of mafic microgranular enclaves in granitoids: equivocal $\mathrm{Sr}-\mathrm{Nd}$ isotopic evidence from Hercynian rocks in the Massif Central (France). Journal of Geophysical Research 95 B, 17821-17828.

Poli, G., 1992. Geochemistry of Tuscan archipelago granitoids, Central Italy: the role of hybridization and accessory phase crystallization in their genesis. Journal of Geology 100, 41-56.

Poli, G., Tommasini, S., 1999. Geochemical modeling of acid-basic magma interaction in the Sardinia-Corsica batholith: the case study of Sarrabus, southeastern Sardinia, Italy. Lithos 46, 553-571.

Poli, G., Tommasini, S., Halliday, A.N., 1996. Trace elements and isotopic exchange during acid-basic magma interaction processes. Transactions of the Royal Society of Edinburgh. Earth Sciences 87, 225-232.

Rapp, R.P., 1995. Amphibole-out phase boundary in partially melted metabasalt, its control over liquid fraction and composition, and source permeability. Journal of Geophysical Research 100 B, 15601-15610.

Rapp, R.P., Watson, E.B., 1995. Dehydration melting of metabasalt at 8-32 Kbar: implication for continental growth and crust-mantle recycling. Journal of Petrology 36, 891-931.

Robertson, H.F., Dixon, J.E., 1984. Introduction: aspects of the geological evolution of the Eastern Mediterranean. In: Dixon, J.E., Robertson, A.H.F. (Eds.), The Geological Evolution of the Eastern MediterraneanGeological Society London, Special Publication, vol. 17 , pp. 1-74.

Rushmer, T., 1991. Partial melting of two amphibolites: contrasting experimental results under fluid-absent conditions. Contributions to Mineralogy and Petrology 107, 41-59.

Sakellariou, D., 1989. Geologie des Serbomazedonischen Massivs in der Nordoestlichen Chalkidiki, N. Griechenland- Deformation und Metamorphose. PhD thesis, Mainz, University of Johannes Gutenberg. In: National and Kapodistrian University of Athens Geological Monographs, 2, pp. 177.

Sapountzis, E., Soldatos, K., Eleftheriades, G., Christofides, G., 1976. Contribution to the study of the Sithonia Plutonic Complex (N. Greece). II. Petrography-Petrogenesis. Annales Géologiques des Pays Helléniques 28, 99-134.

Schmidt, M.W., 1992. Amphibole composition in tonalite as a function of pressure: an experimental calibration of the Al-in-hornblende barometer. Contributions to Mineralogy and Petrology 110, 304-310.
Skjerlie, K.P., Patino Douce, A.E., Johnston, A.D., 1993. Fluid-absent melting of a layered crustal protolith: implications for the generation of anatectic granites. Contributions to Mineralogy and Petrology 114, 365-378.

Snyder, D., Tait, S.R., 1998. The imprint of basalt on the geochemistry of silicic magmas. Earth and Planetary Science Letters 160, 433-445.

Sparks, R.S.J., Marshall, L.A., 1986. Thermal and mechanical constraints on mixing between mafic and silicic magmas. Journal of Volcanology and Geothermal Research 29, 99-124.

Speer, J.A., 1987. Evolution of magmatic AFM mineral assemblages in granitoid rocks: the hornblende + melt $=$ biotite reaction in the Liberty Hill pluton, South Carolina. American Mineralogist 72, 863-878.

Sylvester, P.J., 1998. Post-collisional strongly peraluminous granites. Lithos 45, 29-44.

Tate, M.C., Clarke, D.B., 1997. Compositional diversity among Late Devonian peraluminous granitoid intrusions in the Meguma Zone of Nova Scotia, Canada. Lithos 39, 179-194.

Tsilibari, M., Eleftheriadis, G., 1989. Contribution to the study of pegmatitic veins of Sithonia plutonite. Annales Géologiques des Pays Helléniques 34, 137-148.

Van der Laan, S., Zhang, Y., Kennedy, A., Wyllie, P.J., 1994. Comparison of element and isotope diffusion of $\mathrm{K}$ and $\mathrm{Ca}$ in multicomponent silicate melts. Earth and Planetary Science Letters $123,155-166$.

Vernon, R.H., 1984. Microgranitoid enclaves in granites: globules of hybrid magma quenched in a plutonic environment. Nature 309, 438-439.

Vyhnal, C.R., Mcsween, H.Y., Speer, J.A., 1991. Hornblende chemistry in southern Appalachian granitoids: implications for aluminum hornblende thermobarometry and magmatic epidote stability. American Mineralogist 76, 176-188.

Wolf, M.B., Wyllie, P.J., 1994. Dehydration-melting of amphibolites at 10 Kbar: the effects temperature and time. Contributions to Mineralogy and Petrology 115, 369-383.

Wood, D.A, Joron, J.L., Treuil, M., Norry, M., Tarney, J., 1979. Elemental and $\mathrm{Sr}$ isotope variations in basic lavas from Iceland and the surrounding ocean floor. Contributions to Mineralogy and Petrology 70, 319-339.

Wood, D.A, Tarney, J., Weaver, B.L., 1981. Trace element variations in Atlantic ocean basalts and Proterozoic dykes from Northwest Scotland: their bearing upon the nature and geochemical evolution of the upper mantle. Tectonophysics 75, 91-112.

Zen, E.-An, Hammarstrom, J.M., 1984. Magmatic epidote and its petrologic significance. Geology 12, 515-518. 